\title{
Calibration of a \\ Mathematical Model \\ of the Antelope Valley \\ Ground-Water Basin, \\ California
}

By TIMOTHY J. DURBIN

GEOLOGICAL SURVEY WATER-SUPPLY PAPER 2046

Prepared in cooperation with the

California Department of Water Resources

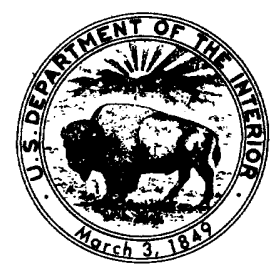

UNITED STATES GOVERNMENT PRINTING OFFICE, WASHINGTON : 1978 


\section{UNITED STATES DEPARTMENT OF THE INTERIOR}

CECIL D. ANDRUS, Secretary

GEOLOGICAL SURVEY

W.A. Radlinaki, Acting Director

Library of Congress Cataloging in Publication Data

Durbin, Timothy J.

Calibration of a mathematical model of the Antelope Valley ground-water basin, California

(Geological Survey water-supply paper 2046)

Bibliography: p. 50-51.

Supt. of Docs. No.: 119.13:2046

1. Water, Underground-California-Antelope Valley-Mathematical models. 2. Watersupply-California-Antelope Valley. I. California. Dept. of Water Resources.

II. Title. III. Series: United S tates. Geological Survey. Water-supply paper 2046.

TC801.U2 no. 2046 [GB1025.C2] 553'.7’0973s [55.14'9'0979495] 78-606198

For sale by the Superintendent of Documents, U. S. Government Printing Office

Washington, D. C. 20402 


\section{CONTENTS}

Conversion factors

Abstract _... 1

Introduction _._.

Well-numbering system

Description of the study area

Location and general features _..... 3

Ground-water geology _._.

Ground-water movement

The mathematical model _... 7

Steady-state model _._. 9

Natural recharge _... 10

Natural discharge ........... 13

Calibration of the steady-state model

Transient-state model _._. 18

Pumpage _......... 19

Irrigation return _...

Selection of net pumpage for model calibration _._.

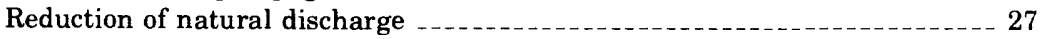

Calibration of the transient-state model

Description of modeling errors - 30

Sources of error

Errors of prediction 35

Numerical solution of the ground-water equations

The Galerkin-finite element concept

Galerkin approximation

Trial functions

Integration of the approximating equation

Finite-difference approximation of the time derivative _._.

Assembly of the two-aquifer solution

Recurrence algorithm 48

Summary _... 49

References cited

\section{ILLUSTRATIONS}

[Plates are in pocket]

Plate 1. Map of Antelope Valley, California, showing geographic setting, generalized geology, boundaries used in the mathematical model, and geologic sections through the ground-water basin.

2. Potentiometric map for 1915, Antelope Valley, California.

3. Potentiometric map for 1961, Antelope Valley, California.

4. Map of Antelope Valley, California, showing finite-element configuration used in the mathematical model of the principal aquifer. 
Plate 5. Map of Antelope Valley, California, showing finite-element configuration used in the mathematical model of the deep aquifer.

6. Map of Antelope Valley, California, showing geographic distribution of natural ground-water recharge and discharge.

7. Map of Antelope Valley, California, showing transmissivity used in the mathematical model of the principal aquifer.

8. Map of Antelope Valley, California, showing transmissivity used in the mathematical model of the deep aquifer.

9. Potentiometric map for 1915 computed by the mathematical model of the principal and deep aquifers, Antelope Valley, California.

10. Map of Antelope Valley, California, showing relative geographic distribution of pumpage from the principal and deep aquifers used in the mathematical model for 1915 through 1961.

11. Map of Antelope Valley, California, showing storage coefficient used in the mathematical model of the principal aquifer.

12. Map of Antelope Valley, California, showing storage coefficient used in the mathematical model of the deep aquifer.

13. Potentiometric map for 1961 computed by the mathematical model of the principal and deep aquifers, Antelope Valley, California.

Figures 1-8. Graphs showing:

1. Relation of stream discharge to drainage area for the San Gabriel

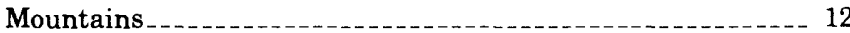

2. Relation of stream discharge to drainage area for the Tehachapi

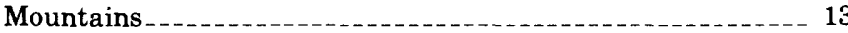

3. Relation of evapotranspiration to depth to water table

4. Relative cumulative distribution of the relative deviation of the model parameters from their initial values _._._._._._._. 17

5. Relative cumulative distribution of the absolute deviation of the computed hydraulic head from the prototype water level for the principal aquifer

6. Relative cumulative distribution of the absolute deviation of the computed hydraulic head from the prototype water level for the principal aquifer within the Lancaster subbasin

7. Previous estimates of the temporal distribution of pumpage

8. Alternative temporal distributions of pumpage for possible use in the mathematical model _._._.

9. Map of part of Antelope Valley, California, showing comparison of ground-water quality for 1908 and 1955 ...................... 24

10. Diagram of decision tree showing selection of net pumpage for calibration of transient-state model ........................ 26

11. Graph showing reduction of evapotranspiration computed by the

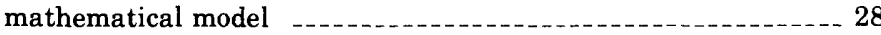

12. Hydrographs of computed hydraulic heads in the principal aquifer at node 144 and measured water levels in well $8 \mathrm{~N} / 13 \mathrm{~W}-11 \mathrm{Q} 1 \ldots 30$

13. Hydrographs of computed hydraulic heads in the principal aquifer at node 248 and measured water levels in well $7 \mathrm{~N} / 11 \mathrm{~W}-28 \mathrm{E} 1 \ldots 31$

14. Graph showing sensitivity of computed hydraulic heads to changes in the storage-coefficient values used in the model ............ 33

15. Graph showing sensitivity of computed hydraulic heads to changes in the transmissivity values used in the model 
FIGURE 16. Finite-element discretization scheme used in the mathematical model

17. Diagram showing local trial function used in the mathematical model 42

\section{TABLES}

TABLE 1. Average annual runoff to Antelope Valley

2. Importance of various possible sources of the deviation of the computed water levels from the prototype water levels

\section{CONVERSION FACTORS}

[Factors for converting English units to metric units are shown to four significant figures. In the text, however, the metric equivalents are shown only to the number of significant figures consistent with the values for the Englısh units]

Engltsh

acres

acre-ft (acre-feet)

acre-ft/yr (acre-feet per year)

(acre-ft/yr)/mi² (acre-feet per year per square mile)

$\mathrm{ft}$ (feet)

$\mathrm{ft} / \mathrm{d}$ (feet per day)

$\mathrm{ft} / \mathrm{mi}$ (feet per mile)

$\mathrm{ft} / \mathrm{yr}$ (feet per year)

$\mathrm{ft}^{2}$ (square feet)

$\mathrm{ft}^{2} / \mathrm{d}$ (feet squared per day)

in. (inches)

in./yr (inches per year)

mi (miles)

$\mathrm{mi}^{2}$ (square miles)
Multiply by- Metric

$4.047 \times 10-1 \quad$ ha (hectares)

$1.233 \times 10-3 \quad \mathrm{hm}^{3}$ (cubic hectometers)

$1.233 \times 10_{-3} \mathrm{hm}^{3} / \mathrm{yr}$ (cubic hectometers per year)

$4.761 \times 10-4 \quad\left(\mathrm{hm}^{3} / \mathrm{yr}\right) / \mathrm{km}^{2}$ (cubic hectometers per year per square kilometer)

$3.048 \times 10_{-1} \mathrm{~m}$ (meters)

$3.048 \times 10_{-1} \mathrm{~m} / \mathrm{d}$ (meters per day)

$1.894 \times 10_{-1} \mathrm{~m} / \mathrm{km}$ (meters per kilometer)

$3.048 \times 10-1 \quad \mathrm{~m} / \mathrm{yr}$ (meters per year)

$9.290 \times 10-2 \quad \mathrm{~m}^{2}$ (square meters)

$9.290 \times 10_{-2} \mathrm{~m}^{2} / \mathrm{d}$ (meters squared per day)

$2.540 \times 10 \quad \mathrm{~mm}$ (millimeters)

$2.540 \times 10 \mathrm{~mm} / \mathrm{yr}$ (millimeters per year)

1.609

2.590 $\mathrm{km}$ (kilometers)

$\mathrm{km}^{2}$ (square kilometers) 


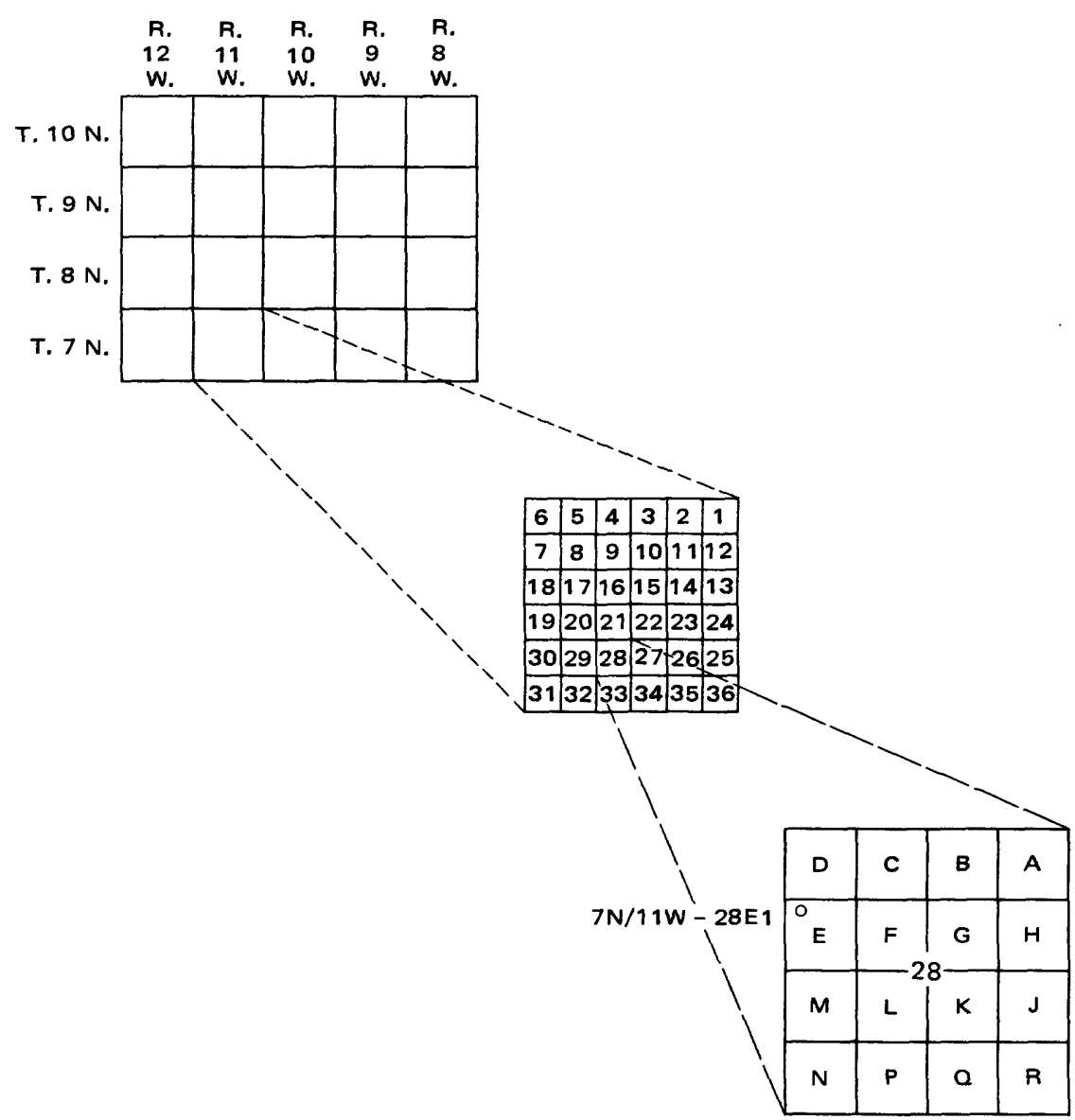

Well-numbering diagram. 


\title{
CALIBRATION OF A MATHEMATICAL MODEL OF THE ANTELOPE VALLEY GROUND-WATER BASIN, GALIFORNIA
}

\author{
By Timothy J. Durbin
}

\begin{abstract}
Antelope Valley is a closed topographic basin in the western part of the Mojave Desert in southern California. A ground-water basin with a surface area of 900 square miles (2,300 square kilometers) and a thickness of as much as 5,000 feet (1,500 meters) underlies the valley floor. The ground-water system consists of two alluvial aquifers separated by fine-grained lacustrine deposits. During the last 50 years, pumpage of ground water in excess of natural recharge has resulted in the steady decline of the ground-water level in the basin. The change in water level has been as much as 200 feet (61 meters). By 1972 the cumulative overdraft was about 9 million acre-feet $(11,000$ cubic hectometers). To help evaluate the possible impact of various water management alternatives, a mathematical model of the ground-water basin was constructed.

Construction of the ground-water model was the first part of a two-part study. The second part of the study will consist of the use of the model to evaluate the impact on the ground-water basin of various water-resource management alternatives. This report describes the mathematical model.

The model was calibrated by comparing the computed hydraulic heads to the corresponding prototype water levels for both steady-state and transient-state conditions. For the steady-state model the area-weighted median deviation of the computed hydraulic heads from the prototype water levels was 12 feet $(3.7$ meters). For the transient-state model the median deviation was 25 feet ( 7.6 meters).

The mathematical model is based on the governing equations of ground-water flow. The solution to the equations was approximated numerically by the Galerkin-finite element method.
\end{abstract}

\section{INTRODUCTION}

Antelope Valley is a large topographic and ground-water basin in the western part of the Mojave Desert in southern California (pl. 1). Ground water has been the principal source of water for economic development in the valley. During the last 50 years, however, pumpage of ground water-chiefly for agricultural uses-in excess of natural recharge has resulted in the steady decline of the groundwater level in the basin. During this period, water levels in wells near 
Lancaster have declined as much as $200 \mathrm{ft}(61 \mathrm{~m})$. By 1972 the cumulative overdraft was about 9 million acre- $\mathrm{ft}\left(11,000 \mathrm{hm}^{3}\right)$.

Antelope Valley is in the service area of the California Water Project. The Project comprises a major system of storage and conveyance facilities for exporting surplus water from northern California (and for transferring this water) to areas of deficiency elsewhere in the State (California Department of Water Resources, 1957). Because of the depletion of local ground-water supplies in Antelope Valley, the Antelope Valley-East Kern Water Agency, the Little Rock Irrigation District, and the Palmdale Water District have contracted for a combined maximum annual entitlement of 158,000 acre-ft $\left(195 \mathrm{hm}^{3}\right)$ of imported water from the California Water Project. Deliveries of this water were begun in 1972 , when 370 acre-ft $\left(0.46 \mathrm{hm}^{3}\right)$ was supplied. Future deliveries will be increased gradually until the maximum entitlement is reached in about 1990 (California State Water Resources Control Board, 1974).

Various plans for the distribution and use of this water are being considered by the responsible water agencies. Plans are being considered also for the reclamation of waste water and the improved utilization of floodwater. To evaluate the possible impact of each alternative on the Antelope Valley ground-water basin, the U.S. Geological Survey and the California Department of Water Resources are engaged in a cooperative investigation.

The investigation was divided into two parts: (1) development of a mathematical model of ground-water flow and (2) use of the model to evaluate the impact of each water-management plan.This report describes the development of the mathematical model. The California Department of Water Resources plans to undertake the application of the model.

\section{WELL-NUMBERING SYSTEM}

Wells are numbered according to their location in the rectangular system for subdivision of public land (see diagram, p. VI). For example, in the well number $7 \mathrm{~N} / 11 \mathrm{~W}-28 \mathrm{E} 1$ the part (of the number) preceding the slash indicates the township (T. $7 \mathrm{~N}$.); the number and letter following the slash indicate the range (R. $11 \mathrm{~W}$.); the number following the hyphen indicates the section (sec. 28); the letter following the section number indicates the 40 -acre (16-ha) subdivision of the section according to the lettered diagram (p.VI) The final digit is a serial number for wells in each 40 -acre (16-ha) subdivision. The area covered by the report lies in the northwest quadrant of the San Bernardino base line and meridian and in the southeast quadrant of the Mount Diablo base line and meridian. 


\section{DESCRIPTION OF THE STUDY AREA}

\section{LOCATION AND GENERAL FEATURES}

Antelope Valley lies in a westward-pointing wedge formed by the intersection of the San Andreas and Garlock fault zones (pl. 1). The valley is bordered on the northwest and north by the Tehachapi Mountains, the Rosamond Hills, and the Bissell Hills; on the southwest and south by the San Gabriel Mountains; and on the east by low hills and divides that separate the valley from upper Mojave Valley, Harper Valley, and Fremont Valley. Mountain and foothill land within Antelope Valley covers about $1,200 \mathrm{mi}^{2}\left(3,100 \mathrm{~km}^{2}\right)$. Relatively flat valley land covers about $1,000 \mathrm{mi}^{2}\left(2,600 \mathrm{~km}^{2}\right)$. The floor of the valley ranges from 2,300 to $3,500 \mathrm{ft}$ (700 to $1,100 \mathrm{~m}$ ) above sea level, thus lying at an altitude higher than most of the nearby desert valleys and considerably higher than the coastal plain to the south and the San Joaquin Valley to the north.

Antelope Valley is characterized by interior drainage that terminates at either Rosamond Lake or Rogers Lake playas. Broad alluvial fans extend as much as $15 \mathrm{mi}(24 \mathrm{~km})$ from the base of the mountains and hills that surround Antelope Valley.

The Antelope Valley ground-water basin covers about $900 \mathrm{mi}^{2}$ $\left(2,300 \mathrm{~km}^{2}\right)$. The basin is divided into ground-water subbasins by faults and other structural features. Subdivisions of the Antelope Valley ground-water basin are the Lancaster, Buttes, Pearland, Neenach, West Antelope, Finger Buttes, and North Muroc subbasins. The names and boundaries of the subbasins that were proposed by Bloyd (1967) are used in this report.

\section{GROUND-WATER GEOLOGY}

The Antelope Valley ground-water basin occupies part of a structural depression that has been downfaulted between the Garlock and San Andreas fault zones. The effect of the faulting was to stimulate erosion of the hills and mountains that surround the valley. The area presently occupied by the ground-water basin became the receptacle for the eroded materials. Economically important aquifers within the ground-water basin occur in the sedimentary deposits that were formed by the deposition of the eroded materials. These deposits have accumulated to a thickness locally of as much as $8,000 \mathrm{ft}(2,400 \mathrm{~m})$ (Mabey, 1960).

Consolidated, virtually non-water-bearing rocks crop out in the highlands that surround the ground-water basin (pl. 1). These rocks also underlie and form the bottom of the ground-water basin. The consolidated rocks consist of igneous and metamorphic rocks, which 
form the basement complex of the study area, and of indurated continental rocks that are interbedded with volcanic flows. The basement complex is of pre-Tertiary age, and the continental rocks are of Tertiary age (Dibblee, 1967).

Water-bearing, mostly unconsolidated deposits that contain sufficient water for economic use overlie the consolidated rocks. The unconsolidated deposits consist of alluvium of Pliocene to Holocene age and of lacustrine deposits of Pleistocene to Holocene age (Dutcher and Worts, 1963) which are interbedded with the alluvium.

\section{Alluvium.}

The alluvium is composed of unconsolidated to moderately indurated, poorly sorted gravel, sand, silt, and clay. Older units of the alluvium are more compacted and indurated, somewhat coarser grained, more weathered, and more poorly sorted than the younger units. The hydraulic conductivity of the alluvium decreases with increasing age (Dutcher and Worts, 1963) and, consequently, with increasing depth.

Dutcher and Worts (1963) identified seven lithographic units within the alluvium. These units are older fan deposits, older alluvium, younger fan deposits, younger alluvium, lakeshore deposits, old wind-blown sand, and dune sand. The older fan deposits comprise old moderately to highly indurated fanglomerate and stream-channel deposits that yield little water to wells. The older alluvium comprises the coarse-grained, weathered, and moderately well-sorted alluvium that underlies the valley areas beneath the younger alluvium. The older alluvium is locally as much as $5,000 \mathrm{ft}(1,500 \mathrm{~m})$ thick, and these deposits constitute the bulk of the water-bearing deposits in the Antelope Valley ground-water basin. The younger fan deposits commonly are composed of very poorly sorted boulders, gravel, sand, silt, and clay. The younger alluvium is composed predominantly of sand and gravel. Prior to about 1945, the younger alluvium was the main source of ground water for agriculture in the Lancaster subbasin, but since that time it has been substantially dewatered. The lakeshore deposits, the old wind-blown sand, and the dune sand are above the regional water table and do not contain significant quantities of ground water.

\section{Lacustrine deposits.}

During the depositional history of the Antelope Valley groundwater basin, a large lake occupied parts of the Lancaster and North Muroc subbasins. Fine-grained lacustrine deposits formed in this lake.

The depositional environment of the lacustrine deposits has varied (Dutcher and Worts, 1963). During pluvial periods, or times of rela- 
tively heavy precipitation, massive beds of blue clay formed in deep, perennial lakes. At least two pluvial periods have been followed by interpluvial periods, during which playa and similar deposits formed in shallow, intermittent lakes. Individual clay beds are locally as much as $100 \mathrm{ft}(30 \mathrm{~m})$ thick. These are interbedded with lenses of coarser material as much as $20 \mathrm{ft}(6.1 \mathrm{~m})$ thick. The clay yields virtually no water to wells, but interbedded materials supply some water to wells.

During deposition of the lacustrine deposits, alluvial debris that was supplied from the San Gabriel Mountains encroached upon the lake, forcing it northward and causing the northward transgression of alluvium over lacustrine deposits. Near the southern limit of the Lancaster subbasin, the lacustrine deposits are buried beneath as much as $800 \mathrm{ft}(240 \mathrm{~m})$ of alluvium, but near the northern limit the lacustrine deposits are exposed at the land surface (pl. 1).

The subsurface extent of the lacustrine deposits is shown on plate 1 . These deposits underlie the central part of the Lancaster subbasin and the southwestern part of the North Muroc subbasin. They extend from near Little Buttes on the west to the east edge of Rogers Lake and from near the southern limit of the Lancaster subbasin on the south to the north edge of Rogers Lake.

The buried body of lacustrine deposits has a somewhat lenticular shape. The thickest section occurs near the center of the Lancaster subbasin (pl. 1), and the unit thins toward its edges. Near Little Buttes and near the east and north edges of Rogers Lake, the unit thins to extinction. Along the northern and southern boundaries of the Lancaster subbasin, the lacustrine deposits terminate against buried escarpments that have formed on the consolidated rocks; the thicknesses along these boundaries are $100 \mathrm{ft}(30 \mathrm{~m})$ and $250 \mathrm{ft}(76$ $\mathrm{m})$, respectively.

The principal and deep aquifers.

Two major aquifers occur within the Antelope Valley ground-water basin: the principal and the deep aquifers (Dutcher and Worts, 1963). The lacustrine deposits separate these aquifers both vertically and horizontally.

The principal aquifer, which supplies nearly all water pumped from wells in the Antelope Valley ground-water basin, overlies the lacustrine deposits (pl. 1) and is unconfined. This aquifer extends over the area to the south and west of Rogers Lake and includes the Neenach, West Antelope, Finger Buttes, Buttes, and Pearland subbasins and part of the Lancaster subbasin (pl. 1).

The deep aquifer, in part, underlies the lacustrine deposits. The extent of this aquifer includes the area of the lacustrine deposits and the area east and north of Rogers Lake. This area includes the North 
Muroc subbasin and part of the Lancaster subbasin (pl. 1). In the area where the deep aquifer is overlain by the lacustrine deposits, the aquifer is confined; in other areas it is unconfined.

\section{GROUND-WATER MOVEMENT}

Ground water in the Antelope Valley ground-water basin moves centripetally from the base of the San Gabriel and Tehachapi Mountains toward the north-central part of the Lancaster subbasin (pl. 2). Before the extensive pumping of ground water, the water table for the principal aquifer was near land surface in the north-central part of the Lancaster subbasin, and ground-water discharge occurred because of direct evapotranspiration of ground water in this area. Pumping of ground water and the subsequent increase in depth to the water table stopped this discharge.

Ground water in the Neenach, West Antelope, and Finger Buttes subbasins moves into the Lancaster subbasin. At the western limit of the lacustrine deposits, part of this water moves over the lacustrine deposits and within the principal aquifer, and part moves under the lacustrine deposits and within the deep aquifer.

Ground water in the Buttes and Pearland subbasins also moves into the Lancaster subbasin. The upper surface of the lacustrine deposits is below the path of the inflowing water, however, and this water moves into the Lancaster subbasin wholly over the top of the lacustrine deposits and within the principal aquifer.

In the Lancaster subbasin, subsurface discharge of ground water in the principal aquifer is impeded by consolidated rocks on the east and north and by the lacustrine deposits on the northeast. Before the 1940 's, ground water in the deep aquifer moved northward out of the Lancaster subbasin, under the lacustrine deposits, and into the North Muroc subbasin. By 1961, the direction of ground-water movement in the deep aquifer had been reversed in the area underlying and immediately south of Rogers Lake, and the direction of ground-water movement there is now southward toward the center of the Lancaster subbasin (pl. 3). North of Rogers Lake, ground water moves from the north Muroc subbasin into Fremont Valley.

Reversal of the direction of ground-water movement in the area south of Rogers Lake was caused for the most part by pumping ground water from the principal aquifer. This pumping also produced significant changes from 1915 to 1961 in water levels in the principal aquifer (pls. 2, 3), especially in the Lancaster subbasin. The main change was the development of areas of low water levels near the west and east sides of the Lancaster subbasin.

Leakage of ground water between the principal and deep aquifers occurs through the lacustrine deposits. Based on hydraulic heads for the principal and deep aquifers that were computed by the mathemat- 
ical model for both steady-state and transient-state conditions, the direction of leakage is downward from the principal aquifer into the deep aquifer along the western and southern periphery of the lacustrine deposits. In the north-central part of the area underlain by lacustrine deposits, the direction of leakage historically was upward from the deep aquifer into the principal aquifer. Because of pumping of ground water from the principal aquifer, the area in which upward leakage occurs is now more toward the south in the areas of concentrated pumping.

Major faults in the Antelope Valley, especially the RandsburgMojave fault, act as partial barriers to the movement of ground water. Water-level differentials of as much as $300 \mathrm{ft}(91 \mathrm{~m})$ occur across the Randsburg-Mojave fault. Along several other faults that cross the Antelope Valley ground-water basin the water table is several tens of feet higher on the upgradient side of the fault than on the downgradient side. The studies of faults near Long Beach, Calif., by Poland, Piper, and others (1956) and near San Bernardino, Calif., by Dutcher and Garrett (1963) indicate that some possible causes of the barrier effect along faults cutting alluvial deposits are (1) local and incomplete offsetting of sand beds against clay beds; (2) sharp local folding of beds near the faults, causing relatively impermeable clay beds to be turned across the direction of ground-water movement; (3) cementation of gravel and sand beds immediately adjacent to the fault by deposition of carbonate minerals from water moving along the fault plane; and (4) development of secondary clayey gouge zones along the faults.

\section{THE MATHEMATICAL MODEL}

A conceptual approach to ground-water modeling was used in this study. First, a conceptual model of the ground-water system, which represents the reduction of the prototype to its essential elements, was developed. Then a mathematical analog, or mathematical model, of the conceptual model was constructed. The mathematical model is a good approximation of the physical processes that were assumed to operate in the conceptual model, but it is only an approximate representation of the prototype.

The conceptualization of the prototype must be simplified to the extent that an operational mathematical model can be constructed; however, simplification must not be so great that the essential characteristics of the prototype are not retained. In practice, our ability to construct mathematical models is limited, and this situation requires that we correspondingly adjust our expectations of the model. We would like a model that represented all characteristics of the prototype but must settle for a model that represents a few of its more important characteristics.

The mathematical model of the Antelope Valley ground-water 
basin is described in following sections. When the model is being discussed, the question of scale invariably arises. It is therefore important to emphasize that this study is being carried out on a megascopic scale. Physical properties and processes observable on a scale of several miles or greater are being considered.

The mathematical model developed for the Antelope Valley ground-water basin treats the prototype as a two-aquifer system. The aquifers are linked together in the model through a leakage term that represents the flow through the lacustrine deposits. As mentioned earlier, the modeling of a ground-water system is accomplished by substituting a simplified conceptual model for the prototype. Some of the more important simplifying assumptions that relate directly to the mathematical model are:

1. Ground-water movement within an aquifer is strictly horizontal.

2. Ground-water movement within the lacustrine deposits is strictly vertical.

3. Hydraulic head changes within the lacustrine deposits do not cause corresponding changes in the volume of water that is stored in these deposits.

4. Changes in ground-water storage in the aquifers occur instantaneously with changes in hydraulic head.

5 . The physical parameters of the system do not change with the state of the system.

6. The aquifers are bounded by an impermeable boundary.

7. Recharge occurs instantaneously.

8. The aquifers are isotropic.

9. The barrier effect of faults can be represented by a zone of low transmissivity.

The general equation that approximately governs the flow of water in a two-dimensional isotropic aquifer is

$$
\frac{\partial}{\partial x}\left(T \frac{\partial h}{\partial x}\right)-\frac{\partial}{\partial y}\left(T \frac{\partial h}{\partial y}\right)-S \frac{\partial h}{\partial t}-W-\frac{K}{b}(h-h a)=0,
$$

where $T$ is the transmissivity of the aquifer, $h$ is the hydraulic head in the aquifer, $S$ is the storage coefficient of the aquifer, $W$ is the flux of a source or $\operatorname{sink}, K$ and $b$ are the vertical hydraulic conductivity and the thickness of the lacustrine deposits, and $h_{a}$ is the hydraulic head in the adjacent aquifer.

The governing equation was solved on triangular elements by the Galerkin-finite-element method. Briefly, the method involved dividing the aquifers into elements having triangular shapes (pls. 4, 5 show the element configurations used for the principal and deep 
aquifers) and assuming that the solution to the governing equation can be expressed as a linear combination of relatively simple trial functions. Associated with the trial functions are coefficients that the Galerkin computational scheme adjusts in order to give some best approximation to equation 1 . The Galerkin-finite-element scheme is described more completely in the section "Numerical Solution of the Ground-Water Equations." A computer program that embodies this solution scheme was written especially for this study.

The geometrical relations in the ground-water basin are specified in the model through the configuration of elements. The physical properties of the prototype are specified in the model by assigning parameter values to the elements. These values represent the prototype transmissivity, storage coefficient (for the transient-state model), and, where appropriate, the thickness and vertical hydraulic conductivity of the confining member. The model uses the above specifications to compute hydraulic heads that mathematically satisfy the physical parameters of the system and also satisfy the rate of inflow and outflow that is applied.

One important source of uncertainty in the model is the unavoidable lack of definitive measurements of the model parameters. The aggregate character of these parameters makes laboratory measurements of little use. Current methods of field testing, such as aquifer tests, are of limited use in providing values that can be used directly or extrapolated reliably to the large-scale phenomena simulated by the model.

To improve the prior estimates of these parameters, the model was calibrated by iteratively adjusting the parameter values until the model reproduced historical conditions to an acceptable degree. The model was calibrated to two different historical conditions, first to a steady-state condition and second to a transient-state condition. These calibrations were subjective and, to a large extent, based on trial and error.

\section{STEADY-STATE MODEL}

Prior to the entry of man into Antelope Valley, the ground-water basin was in an equilibrium or steady-state condition: recharge equaled discharge and, considering periods of several years, the water levels in the ground-water basin remained unchanged with time. Several hundred wells were drilled in Antelope Valley prior to 1908, but the wells were used primarily to secure patents to government land (Snyder, 1955). The significant use of ground water for irrigation began in about 1915, and before this date the ground-water basin can be considered to have been in an equilibrium state.

The steady-state model of the Antelope Valley ground-water basin is intended to represent this condition. Input to the steady-state 
model is the natural recharge and discharge of ground water. Output from the model is the primordial hydraulic heads in the principal and deep aquifers. The calibration problem for this model was to refine prior estimates of the transmissivity of the principal and deep aquifers and prior estimates of the vertical hydraulic conductivity of the lacustrine deposits that separate these aquifers.

\section{NATURAL RECHARGE}

Occurrence of natural recharge.

The Antelope Valley ground-water basin is recharged naturally by infiltration of streamflow that originates in the mountain areas contiguous to the ground-water basin. For the most part, streamflow that enters the valley is ephemeral. During storm periods, streamflow debouches along the valley perimeter and moves down the alluvial fans and toward Rosamond and Rogers Lake playas. As streamflow moves down the alluvial fans, it infiltrates the permeable surficial deposits on the fans and seldom reaches the playas. The infiltrate is partly evaporated and partly transpired by riparian vegetation. The remainder percolates through the alluvial deposits until it reaches the water table.

Because the average annual precipitation on the valley floor is less than $10 \mathrm{in} .(250 \mathrm{~mm})$ (Rantz, 1969), very little runoff is generated on the valley floor, and probably very little precipitation penetrates below the root zone. In an environment somewhat similar to that of Antelope Valley, Blaney, Taylor, and Young (1930) and Young and Blaney (1942) found that precipitation does not penetrate below the root zone if the annual precipitation is less than about 12 in. (300 $\mathrm{mm}$ ). Therefore, precipitation on the valley floor was not considered to be an important source of ground-water recharge.

In the mountain areas the average annual precipitation is generally greater than 12 in. ( $300 \mathrm{~mm})$ (Rantz, 1969). Part of this precipitation becomes surface runoff, and part becomes soil moisture. For most of the mountain areas, precipitation that infiltrates the soil mantle is in excess of the moisture requirements of vegetation and soil evaporation. Much of the surplus soil moisture moves along the subsurface contact between a thin soil mantle and the underlying bedrock. This water moves downslope and eventually may reach the ground-water basin.

Two important sources of ground-water recharge are possible: streamflow infiltration and near-surface horizontal percolation. The net recharge of ground water from both sources is equal to the total surface-water flow onto the valley floor, plus the total subsurface inflow, minus the total quantity of water removed from stream channels by evapotranspiration. Unfortunately, practical techniques are not available for estimating the subsurface inflow or the quantity of 
evapotranspiration from the stream channels. The assumption that was made is that these two quantities are locally equal and that the local net recharge is numerically equal to the surface-water discharge from the mountains onto the valley floor.

Mean annual streamflow.

The drainage area tributary to the Antelope Valley ground-water basin is about $385 \mathrm{mi}^{2}\left(1,000 \mathrm{~km}^{2}\right)$. Runoff from about 20 percent of this area is gaged. Runoff records (table 1) are available for Big Rock Creek near Valyermo, Little Rock Creek near Little Rock, and Santiago Creek above Little Rock Creek, all in the San Gabriel Mountains (pl. 6). The collective mean annual discharge at these points is about 24,300 acre-ft $\left(30.0 \mathrm{hm}^{3}\right)$. The mean annual runoff from other areas of Antelope Valley was estimated by using a method that is based on the measurement of the width and average depth of stream channels at bars and berms.

An alluvial channel adjusts in size to accommodate the discharge it receives (Moore, 1968; Leopold and Wolman, 1957). Although the channel geometry is influenced by the channel slope and pattern, sediment loads, cohesiveness of the banks, and vegetation, studies by Moore (1968) indicate that the dimensions of cross sections at the bars and berms are not significantly affected by these factors and that the dimensions of cross sections are related to the mean annual runoff. Using the width $(W)$ and depth $(D)$ in feet at bars and berms, Hedman (1970) developed, from southern California streamflow data, the empirical relation

$$
Q=258 W^{0.80} D^{0.60}
$$

for estimating the mean annual discharge $(Q)$ in acre-feet. The standard error of estimate for the relation was 29 percent.

The channel-geometry relation was used to estimate the mean annual discharge for 25 ungaged streams. Channel geometry was measured in 11 stream channels in the San Gabriel Mountains and 14 stream channels in the Tehachapi Mountains. The cumulative drainage area above the measurement points is about 27 percent of the ungaged tributary area in the San Gabriel Mountains and about 40 percent of the drainage area in the Tehachapi Mountains.

The estimated discharge at the channel-geometry measurement locations was extrapolated to other ungaged areas by the relation

$$
Q=C A \text {, }
$$

where $Q$ is the mean annual runoff, $A$ is the drainage area, and $C$ is the average ratio of runoff to the drainage area at the channelgeometry-measurement locations. The value of $C$ for the San Gabriel Mountains (fig. 1) was $50($ acre- $\mathrm{ft} / \mathrm{yr}) / \mathrm{mi}^{2}\left[0.024\left(\mathrm{hm}^{3} / \mathrm{yr}\right) / \mathrm{km}^{2}\right]$. The value of $C$ for the Tehachapi Mountains (fig. 2) was 60 (acre-ft/yr) $/ \mathrm{mi}^{2}$ [0.029 $\left.\left(\mathrm{hm}^{3} / \mathrm{yr}\right) / \mathrm{km}^{2}\right]$. 
DRAINAGE AREA, IN SQUARE KILOMETERS

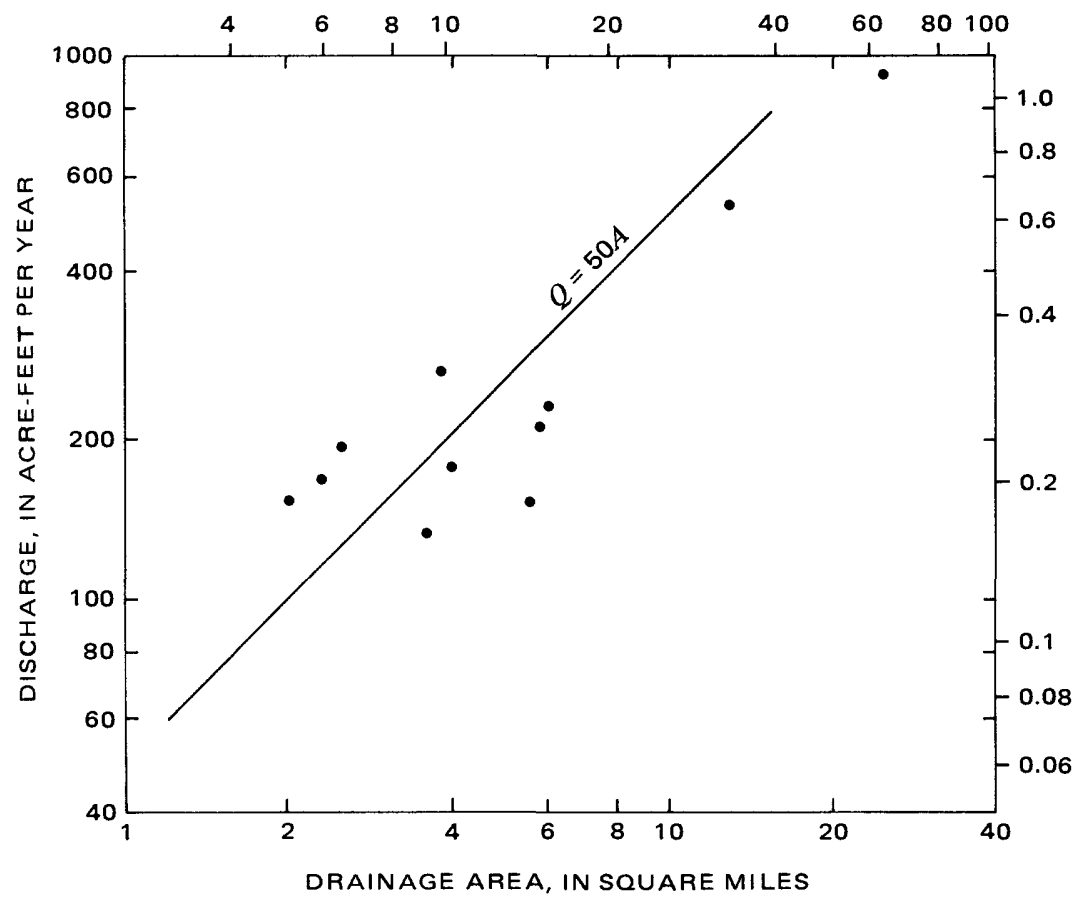

Figure 1.-Relation of stream discharge to drainage area for the San Gabriel Mountains.

By using the coefficient values, the cumulative average annual runoff from the ungaged drainage basins was estimated to be 16,400 acre-ft $\left(20.2 \mathrm{hm}^{3}\right)$ (table 1). The total average annual runoff from

TABLE 1.-Average annual runoff to Antelope Valley

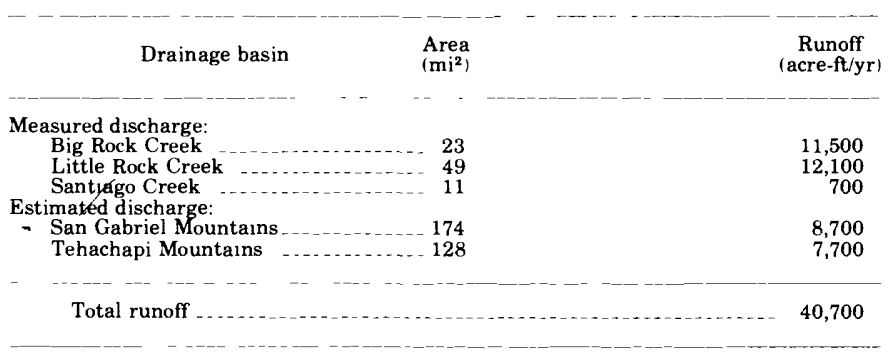

both gaged and ungaged drainage basins is 40,700 acre-ft $\left(50 \mathrm{hm}^{3}\right)$. Natural recharge to the ground-water basin, which was assumed to be numerically equivalent to runoff, was distributed geographically as shown on plate 6 . 
DRAINAGE AREA, IN SQUARE KILOMETERS

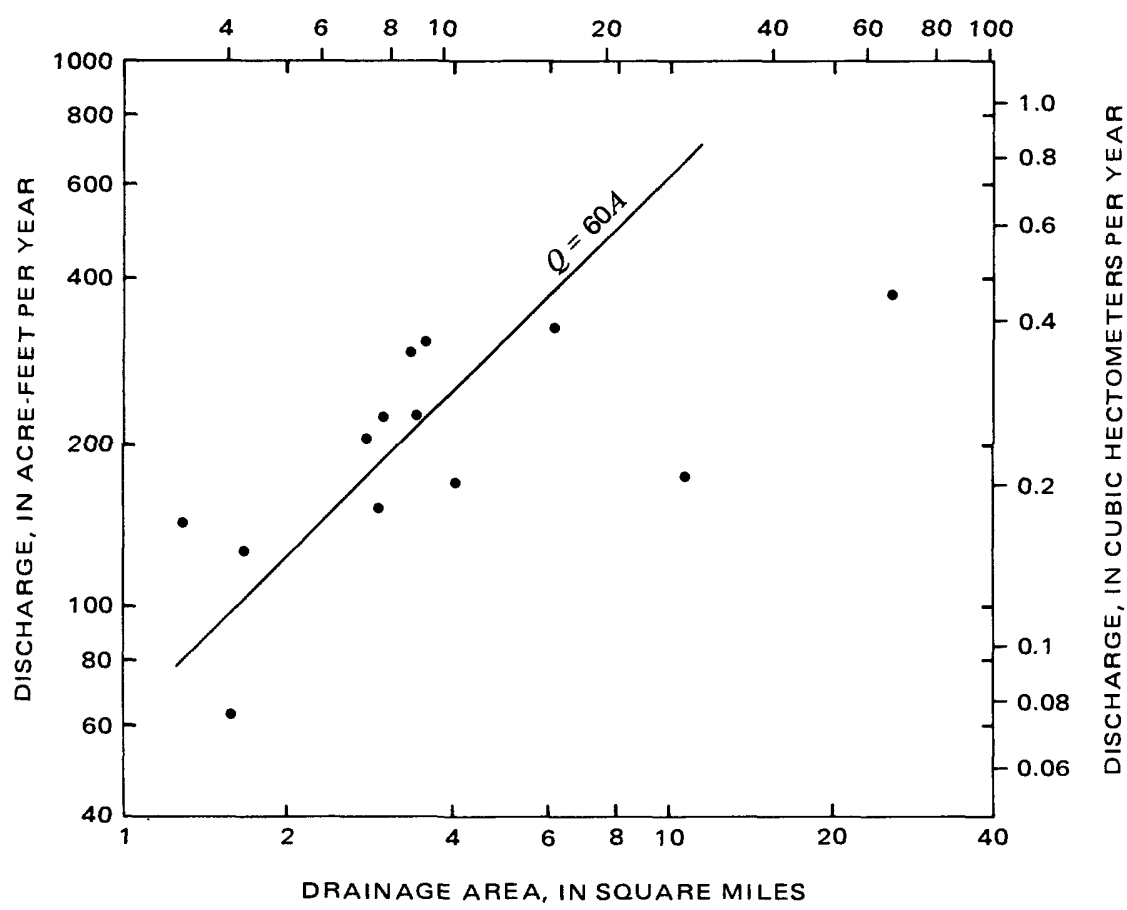

FIgURE 2.-Relation of stream discharge to drainage area for the Tehachapi Mountains.

\section{NATURAL DISCHARGE}

Average annual discharge from ground water over an extended period of time will equal average annual recharge when there is no interference by man. Because of heavy pumping, however, natural discharge has been substantially reduced. Prior to the pumping of ground water, natural discharge occurred by subsurface outflow, by evapotranspiration, and by springs. Subsurface outflow and evapotranspiration were the principal mechanisms for natural discharge. The discharge of springs was not significant and was probably less than 300 acre-ft/yr $\left(0.37 \mathrm{hm}^{3} / \mathrm{yr}\right)$ (Thompson, 1929; Johnson, 1911).

Subsurface outflow.

North of Rogers Lake, the land surface along the divide between Antelope Valley and Fremont Valley is less than $100 \mathrm{ft}(30 \mathrm{~m})$ higher than the lowest point in Antelope Valley. Although consolidated rocks crop out on both sides, the divide for a width of about $1 \mathrm{mi} \mathrm{(1.6}$ $\mathrm{km})$ is underlain by as much as $1,000 \mathrm{ft}(300 \mathrm{~m})$ of unconsolidated deposits. At this location some ground water is discharged from 
the Antelope Valley ground-water basin into the Fremont Valley ground-water basin as subsurface outflow (pl. 6).

The quantity of subsurface outflow can be approximated by the relation

$$
Q=A K\left(\frac{\partial h}{\partial n}\right)
$$

where $Q$ is the subsurface outflow, $A$ is the cross-sectional area of flow, $K$ is the hydraulic conductivity of the unconsolidated deposits, and $\partial h / d n$ is the hydraulic-head gradient. Based on the subsurface projection of the exposed consolidated rocks beneath the unconsolidated deposits and on the measurement of the depth to ground water, the cross-sectional area of flow is about $1.2 \times 10^{6} \mathrm{ft}^{2}\left(1.1 \times 10^{5} \mathrm{~m}^{2}\right)$. Aquifer test data (Moyle, 1965) indicate that the hydraulic conductivity of the unconsolidated deposits is about $50 \mathrm{ft} / \mathrm{d}(15 \mathrm{~m} / \mathrm{d})$. The water-level gradient is about $10 \mathrm{ft} / \mathrm{mi}(1.9 \mathrm{~m} / \mathrm{km})$. The substitution of these values into equation 4 gives an estimated subsurface outflow of 1,000 acre-ft/yr $\left(1.2 \mathrm{hm}^{3} / \mathrm{yr}\right)(\mathrm{pl} .6)$.

\section{Evapotranspiration.}

Large areas of alkali soil in the Lancaster subbasin (pl. 6) indicate a former discharge of ground water by evapotranspiration (Carpenter and Cosby, 1926). The alkali was dissolved in ground water, and as the result of evapotranspiration the alkali and other dissolved solids were precipitated out of solution at or near the land surface.

Ground-water discharge by evapotranspiration generally occurs when the water table is within about $10 \mathrm{ft}(3 \mathrm{~m})$ of the land surface. Under this condition some plant species obtain their water supply from either the ground water or the capillary fringe, and the consumption of ground water by this vegetation is an important mechanism for ground-water discharge. If the water table is within a foot or so of land surface, significant quantities of ground water may additionally be discharged by direct evaporation of water from the capillary fringe. The mass balance for the Antelope Valley groundwater basin indicates that the annual discharge of ground water by evapotranspiration may have been about 39,400 acre-ft $\left(48.5 \mathrm{hm}^{3}\right)$.

Where a linear relation between the depth to the water table and the ground-water discharge is assumed, the relation can be defined if two points on the relation are specified. For example, salt grass (Distichlis stricta) was the principal plant species in the area of evapotranspiration in Antelope Valley (Thompson, 1929). Robinson (1958) reported that for a depth to the water table of $1 \mathrm{ft}(0.3 \mathrm{~m})$ evapotranspiration from salt grass may be as much as 75 percent of the pan evaporation. The pan evaporation in Antelope Valley is about 114 
in./yr $(2,900 \mathrm{~mm} / \mathrm{yr})$ (Bloyd, 1967), and 75 percent of this value is 86 in./yr $(2,180 \mathrm{~mm} / \mathrm{yr})$. Lysimeter studies by Lee (1912) indicate that evapotranspiration from salt grass virtually stops if the depth to the water table is greater than $10 \mathrm{ft}(3.0 \mathrm{~m})$. The data from Robinson and Lee give two points on the depth-discharge relation for salt grass, and, given the assumption above, these data are sufficient to define the linear relation that is shown in figure 3.

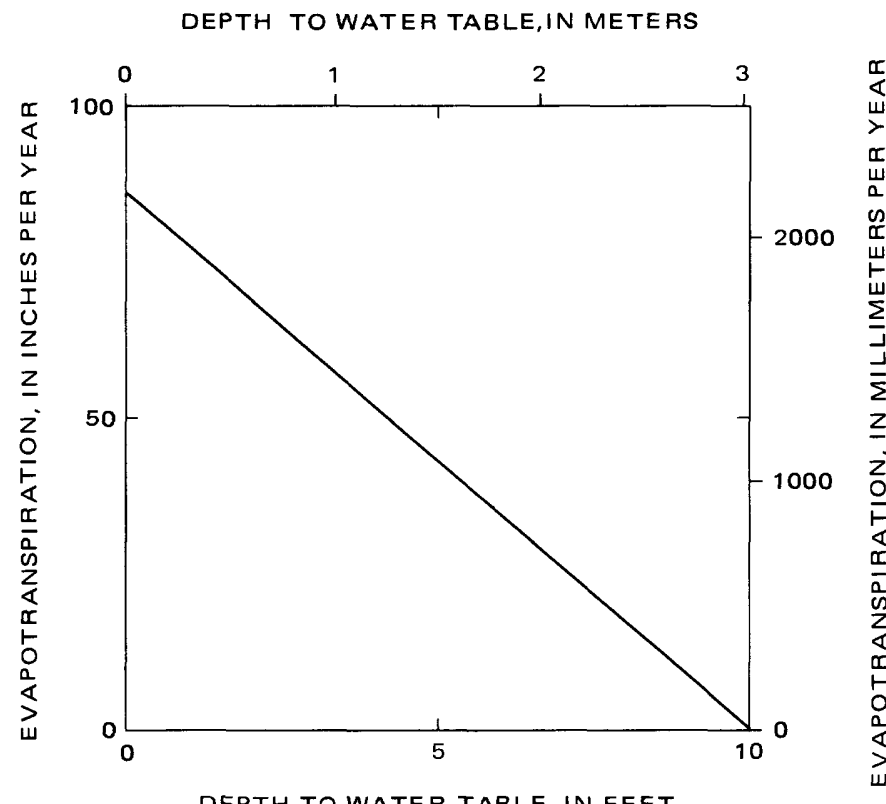

Figure 3.-Relation of evapotranspiration to depth to water table.

\section{CALIBRATION OF THE STEADY-STATE MODEL}

The steady-state model was calibrated to the estimated prototype water levels for 1915 (pl. 2). Most of the first wells in Antelope Valley were drilled in the Lancaster subbasin. Consequently, most of the early water-level measurements were made in wells that were located there. For these wells, Johnson (1911) reported water-level measurements that he made in the winter of 1908-09. Thompson (1929) reported water-level measurements that he and others made during 1907-21. In most instances, these water-level measurements can reasonably be assumed to represent conditions existing in 1915 .

Few early water-level measurements are available for the area outside the Lancaster subbasin, but water levels in much of this area have not changed more than a few tens of feet since 1915. Water-level measurements that were made as late as 1965 (Dutcher and others, 
1962; Moyle, 1965; Koehler, 1966) were assumed to represent the water-level conditions existing in 1915. Nevertheless, in the area outside the Lancaster subbasin, the geographic distribution of available water-level measurements is not complete, and the estimated water levels in this area were based mainly on the subjective extrapolation of sparse data.

The measured water levels represent for the most part the waterlevel conditions in the principal aquifer. In the part of Antelope Valley south and west of Rogers Lake, no field data are available that indicate the hydraulic head in the deep aquifer. Some water-level measurements are available for wells in the deep aquifer in the area north and east of Rogers Lake.

In addition to requiring estimates of the water levels, the calibration procedure requires that initial estimates be made of the transmissivity of the principal and deep aquifers and of the vertical hydraulic conductivity of the lacustrine deposits.

The initial estimates of the transmissivity of the principal aquifer were based on specific-capacity data reported by Bloyd (1967). Transmissivity of the aquifer can be estimated by multiplying the specific capacity of a properly constructed well by a factor (Theis, 1963). If homogeneous units of measure are used for both the specific capacity and the transmissivity, the factor is dimensionless, and its value ranges between 1.0 and 1.4. The correct value of the factor depends in part on the duration of the pumping tests used to estimate the specific capacity of a well. The data reported by Bloyd (1967) are based on pumping tests of short duration, and a value of 1.0 was used for the factor.

Field data are not available for estimating the transmissivity of the deep aquifer, except in the vicinity of Rogers Lake where some wells penetrate this aquifer. In other areas of the valley, data on transmissivity are not available from the wells that penetrate the deep aquifer. The specific-capacity data reported by Bloyd (1967) were used to estimate transmissivity in the limited area for which these data are available. Transmissivity for the deep aquifer in other areas was prescribed subjectively.

The vertical hydraulic conductivity of the lacustrine deposits was estimated from sparse field data. Based on the probable properties of the lacustrine deposits, a value of $10^{-2} \mathrm{ft} / \mathrm{d}\left(3 \times 10^{-3} \mathrm{~m} / \mathrm{d}\right)$ was assumed for the vertical hydraulic conductivity of the lacustrine deposits. Using this value in the model, computed head differences between the aquifers were comparable to those presumed to have existed in the prototype, which are generally less than $20 \mathrm{ft}(6.1 \mathrm{~m})$, and the value was not changed during calibration.

Hydraulic heads in the principal and deep aquifers were computed using estimates of the system parameters that are described above. 
Originally these heads deviated locally as much as $500 \mathrm{ft}(150 \mathrm{~m})$ from the prototype water levels. The objective of the calibration was to reduce the local deviations to a reasonable level by adjusting the system parameters within a range of physically plausible values.

During calibration of the steady-state model, adjustments were made primarily to the transmissivity of the principal aquifer. Twenty-two calibration runs were made. During the early runs, gross adjustments were made to the transmissivity of large areas. Finer adjustments were made to the transmissivity over smaller areas during the later calibration runs. The net effect of these adjustments was to increase the transmissivity by about 15 percent above the initial estimates (fig. 4). The adjusted transmissivity of the principal aquifer is shown on plate 7 , and the adjusted transmissivity of the deep aquifer is shown on plate 8 .

Plate 9 shows hydraulic heads in the principal and deep aquifers computed by the mathematical model using the transmissivity distributions shown on plates 7 and 8 . The shape of the computed solu-

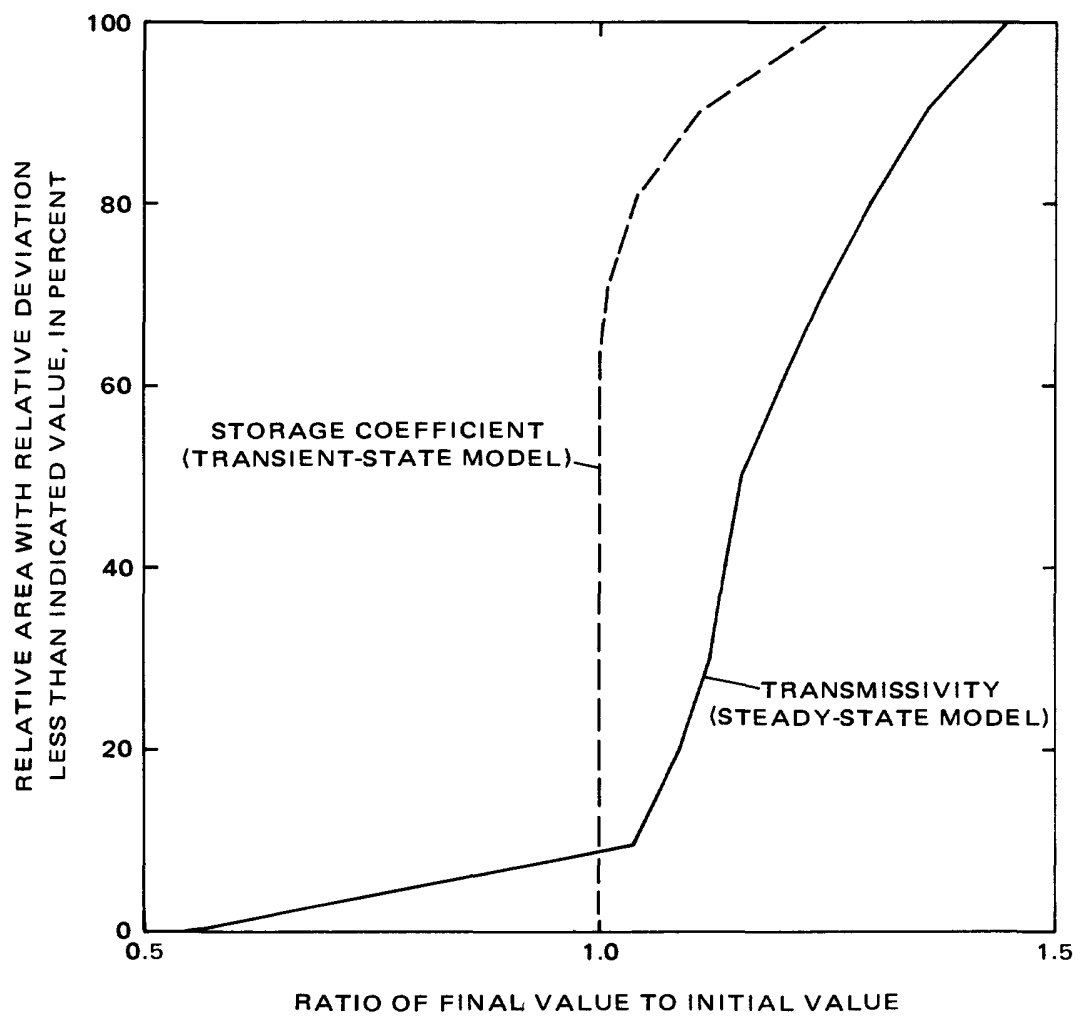

Figure 4.-Relative cumulative distribution of the relative deviation of the model parameters from their initial values. 
tion compares well with the potentiometric map of the prototype water levels for the principal aquifer shown on plate 2 . The areaweighted median absolute deviation of computed hydraulic heads from prototype water levels is $12 \mathrm{ft}(3.7 \mathrm{~m})$ (fig. 5). The largest devia-

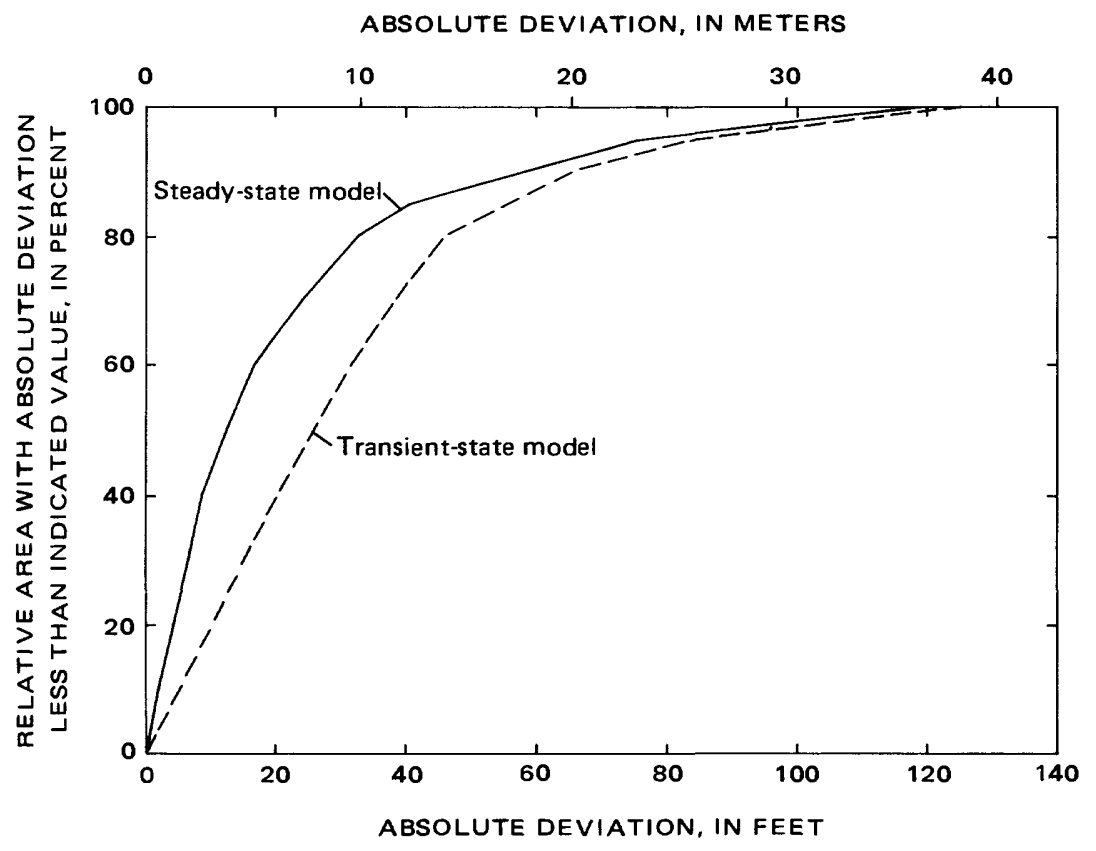

FIGURE 5.-Relative cumulative distribution of the absolute deviation of the computed hydraulic head from the prototype water level for the principal aquifer.

tions occur in areas where sparse field data introduce considerable uncertainty into the estimates of the prototype water levels. Field data are available for most of the Lancaster subbasin, and for this area the median absolute deviation was $7 \mathrm{ft}(2.1 \mathrm{~m})$ (fig. 6).

\section{TRANSIENT-STATE MODEL}

The use of ground water in Antelope Valley for agriculture disturbed the primordial equilibrium in the ground-water basin. Over much of the period of ground-water use, the net extraction of ground water has been in excess of the net natural recharge of ground water. As a result, the overall ground-water trend in Antelope Valley has been one of declining water levels. Hydrographs of wells perforated in the principal aquifer indicate that from 1920 through 1972 the water level in this aquifer declined as much as $200 \mathrm{ft}(61 \mathrm{~m})$. The rate of decline has been as much as $4 \mathrm{ft} / \mathrm{yr}(1.2 \mathrm{~m} / \mathrm{yr})$.

The transient-state model of the Antelope Valley ground-water 
ABSOLUTE DEVIATION, IN METERS

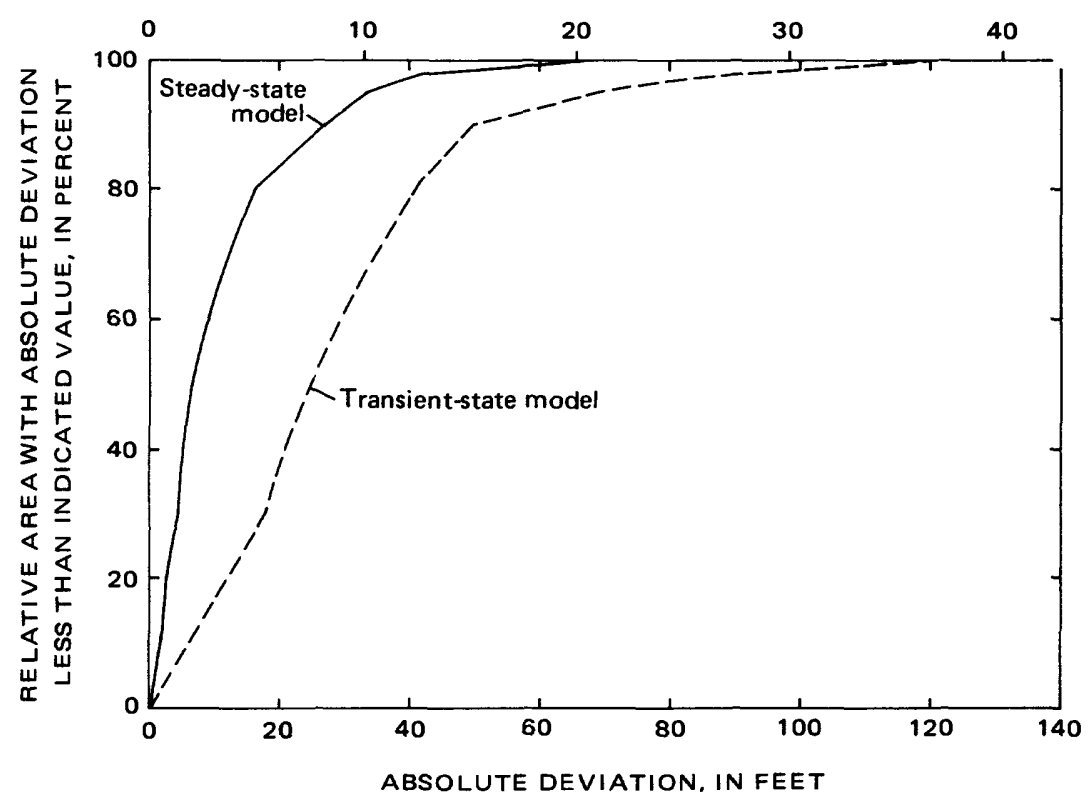

Figure 6.-Relative cumulative distribution of the absolute deviation of the computed hydraulic head from the prototype water level for the principal aquifer within the Lancaster subbasin.

basin is intended to represent temporal changes of water levels in the basin. The input to the model is natural recharge of ground water (which was presumed to be the same as the natural recharge that was used in the steady-state model), pumpage of ground water, irrigation return, and the reduction of natural discharge. The output from the model is the change of hydraulic head with time in the principal and deep aquifers. The calibration problem for this model was the modification of prior estimates of the storage coefficient of the aquifers.

\section{PUMPAGE}

In Antelope Valley the use of ground water for agricultural purposes began in about 1880 , when it was discovered that wells drilled in the lower part of the valley yielded flowing water in quantities sufficient for irrigation (Thompson, 1929). In 1891 more than 100 wells were in use, but by that time only a few wells were flowing (R. J. Henton, as cited in Wright, 1924). Drilling of large numbers of wells began shortly before 1920 (Wright, 1924). Data presented by Snyder (1955) indicate a rapid increase in the number of wells immediately after that date; hence, it seems that the effective beginning of ground-water use in Antelope Valley is 1915. 
As the number of wells in Antelope Valley increased, the quantity of water discharged by wells also increased. In 1924 about 55,000 acre-ft $\left(68 \mathrm{hm}^{3}\right)$ of water was pumped. By 1930 the annual pumpage had increased to 170,000 acre-ft $\left(210 \mathrm{hm}^{3}\right)$ (Snyder, 1955). During the period of economic depression following 1930 , pumpage declined until in 1933 the annual pumpage was about 95,000 acre-ft $\left(117 \mathrm{hm}^{3}\right)$. After 1933, pumpage again increased until about 1950, when the annual pumpage reached the highest value of about 300,000 acre-ft $\left(400 \mathrm{hm}^{3}\right.$ ) (Snyder, 1955; California State Water Resources Control Board, 1974). Declining water levels resulted in uneconomically high pumping lifts in some parts of Antelope Valley, and pumpage again declined after 1950. In 1972 the annual pumpage was about 200,000 acre-ft $\left(200 \mathrm{hm}^{3}\right)(\mathrm{K}$. W. Mido, California Department of Water Resources, written commun., 1973).

Long-term changes in the pumping rate usually correspond to changes in the acreage under irrigation in Antelope Valley. An increase in pumpage usually means that new land has been brought under irrigation; a decrease in pumpage means that land has been removed from irrigation. At the time of the highest pumping rate, about 70,000 acres (28,000 ha) of land were under irrigation (Snyder, 1955). At that time the irrigated land in Antelope Valley was mostly in the Lancaster subbasin. About two-thirds of the irrigated land was in the eastern part of the subbasin, and the remaining irrigated land was in the western part. The central part of the Lancaster subbasin has not been extensively irrigated.

On the basis of data presented by California Department of Water Resources (1947; K. W. Mido, written commun., 1973), the geographic distribution of irrigated land and of pumpage (pl. 10) in Antelope Valley remained generally unchanged from 1915 through 1961 , although local changes in both did occur. After about 1961 the geographic distribution of irrigated land changed. The centroid of irrigated land in the eastern part of the Lancaster subbasin moved about $10 \mathrm{mi}(16 \mathrm{~km})$ south of its former position, and the centroid of irrigated land in the western part of the subbasin moved about $10 \mathrm{mi}$ $(16 \mathrm{~km})$ north of its former position. These shifts in the geographic distribution of irrigated land were related in part to the decline of ground-water levels in the Lancaster subbasin; irrigation was abandoned where pumping lifts became uneconomically high.

Snyder (1955), California Department of Water Resources (K. W. Mido, written commun., 1973), California State Water Resources Control Board (1974), and Antelope Valley-East Kern Water Agency (W. G. Spinarski, written commun., 1976) have estimated the annual pumpage in Antelope Valley for periods ranging from 1 to 28 years (fig. 7). The estimates of pumpage that were made by these different 


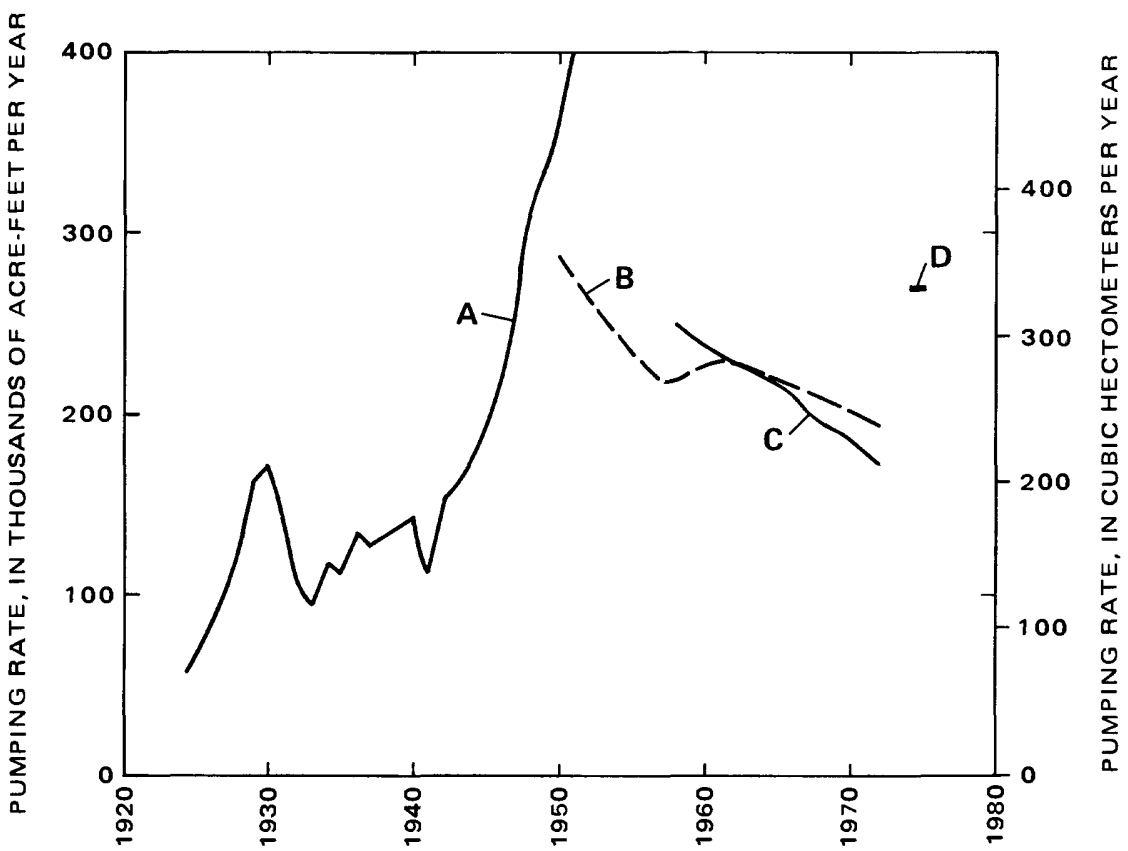

Figure 7.-Previous estimates of the temporal distribution of pumpage. Curve $A$ is the estimate by Snyder (1955). Curve B is the estimate by California State Water Resources Control Board (1974). Curve C is the estimate by California Department of Water Resources (K. W. Mido, written commun., 1973). Curve D is the estimate by Antelope Valley-East Kern Water Agency (W. G. Spinarski, written commun., 1976).

investigators do not agree where the periods covered by the estimates are coincident. For example, Snyder (1955) estimated that the annual pumpage in 1950 was 362,000 acre-ft $\left(446 \mathrm{hm}^{3}\right)$, and California State Water Resources Control Board (1974) reported this pumpage to be 285,000 acre-ft $\left(351 \mathrm{hm}^{3}\right)$.

The data shown in figure 7 are only estimates of the true pumpage, and individual data points would be expected to deviate from the true pumpage. If, however, the pumpage used in the calibration of the transient-state model deviates from the true value, the estimates of the storage-coefficient values obtained from the calibration most likely will also deviate from the true values. Thus, it becomes important to devise a method that will allow estimation of the pumpage as accurately as possible.

A commonly used method for improving estimates of a quantity is to average several estimates. This average is, as are the original estimates on which it is based, only an approximation of the true value. The probable deviation of the average from the true value, 
however, will generally be smaller than the probable deviation of any one of the original estimates from the true value.

The pumpage curve $A$ in figure 8 represents an average of the pumpage data shown in figure 7 . This curve was constructed by giving approximately equal weight to the curves $A, B, C$, and D in figure 7 (curve $D$ was extrapolated backward in time parallel to general trend of curves $B$ and $C$ until it intersected curve A). Other estimates of the true pumpage can be obtained by giving unequal weight to the available data. Curve $B$ in figure 8 represents an unequally weighted average of the data in figure 7 . For this average, little weight was given to curve $D$ because of the short time interval covered by the estimate.

By giving different weights to the available data, pumpage estimates within a continuous range can be developed. The weights used in the development of curves $A$ and $B$ in figure 8 represent two reasonable interpretations of the pumpage data, and other pumpage data were not considered. The problem remains, however, to choose which of these pumpages to use in the calibration of the model. A discussion of this is held until later.

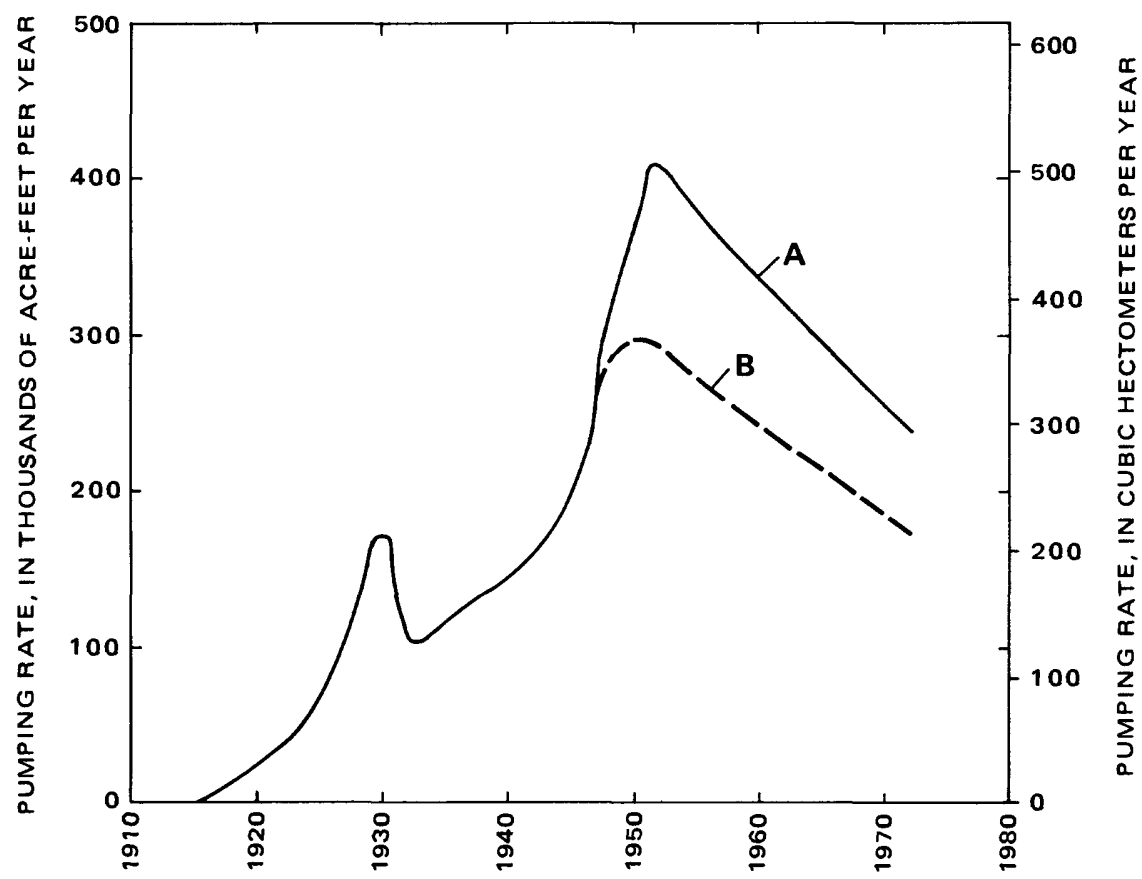

Figure 8.-Alternative temporal distributions of pumpage for possible use in the mathematical model. Curve $A$ is the average of all data shown in figure 7 . Curve $B$ is the average of curves $\mathrm{A}, \mathrm{B}$, and $\mathrm{C}$ in figure 7 . 


\section{IRRIGATION RETURN}

When land is being irrigated, water in excess of the moisture requirement of crops is applied to control the salt level in the root zone. The question arises as to the fate of water that gets below the root zone. If part of the applied water percolates downward until it reaches the zone of saturation, it becomes available for reuse.

A necessary input to the model is the quantity of water returned to the zone of saturation. Estimates of irrigation return are necessarily linked with estimates of pumpage, which was discussed in the previous section. Snyder (1955) estimated that in Antelope Valley about 70 percent of the applied water is actually consumed by the crop or otherwise lost and that the mean annual application of water to the irrigated lands is about $6 \mathrm{ft}(1.8 \mathrm{~m})$. Correspondingly, the mean annual percolation past the root zone is about $2 \mathrm{ft}(0.6 \mathrm{~m})$. This percolate moves generally downward through the unsaturated zone toward the water table. Two separate lines of evidence, however, suggest that by about 1955 most of this water had not reached the water table.

The first line of evidence involves a consideration of the historical trend of the dissolved-solids concentration in water below the water table. If the irrigation-return percolate, which has a dissolved-solids concentration of about $700 \mathrm{mg} / \mathrm{l}$ (milligrams per liter) (R. E. Lewis, written commun., 1976), is mixing with water below the water table, which from 1908 through 1955 had a concentration of about $250 \mathrm{mg} / \mathrm{l}$ (Johnson, 1911; Koehler, 1966; Moyle, 1965), the concentration below the water table probably should have increased with time. For 1908 through 1955, however, a general increase in dissolved-solids concentration was not observed (fig. 9), which tends to support the assumption that by 1955 the irrigation-return percolate had not reached the water table. During the 1960's the concentration did increase, suggesting that during that period the percolate began to mix with ground water.

The second line of evidence involves the existence of perched ground-water bodies. The presence of perched ground water in Antelope Valley is indicated by falling water in some wells. The development of perched ground-water bodies indicates the presence of subsurface geologic conditions that retard the downward movement of the irrigation-return percolate. Thus, the perched ground-water bodies provide the mechanism for the retention of irrigation-return percolate above the water table.

The evidence supporting the assumption that most of the percolate was retained above the water table during the model calibration period, 1915 through 1961, is not conclusive, and significant uncertainty exists as to the true state of the prototype. The resolution of this uncertainty is discussed in the following section. 


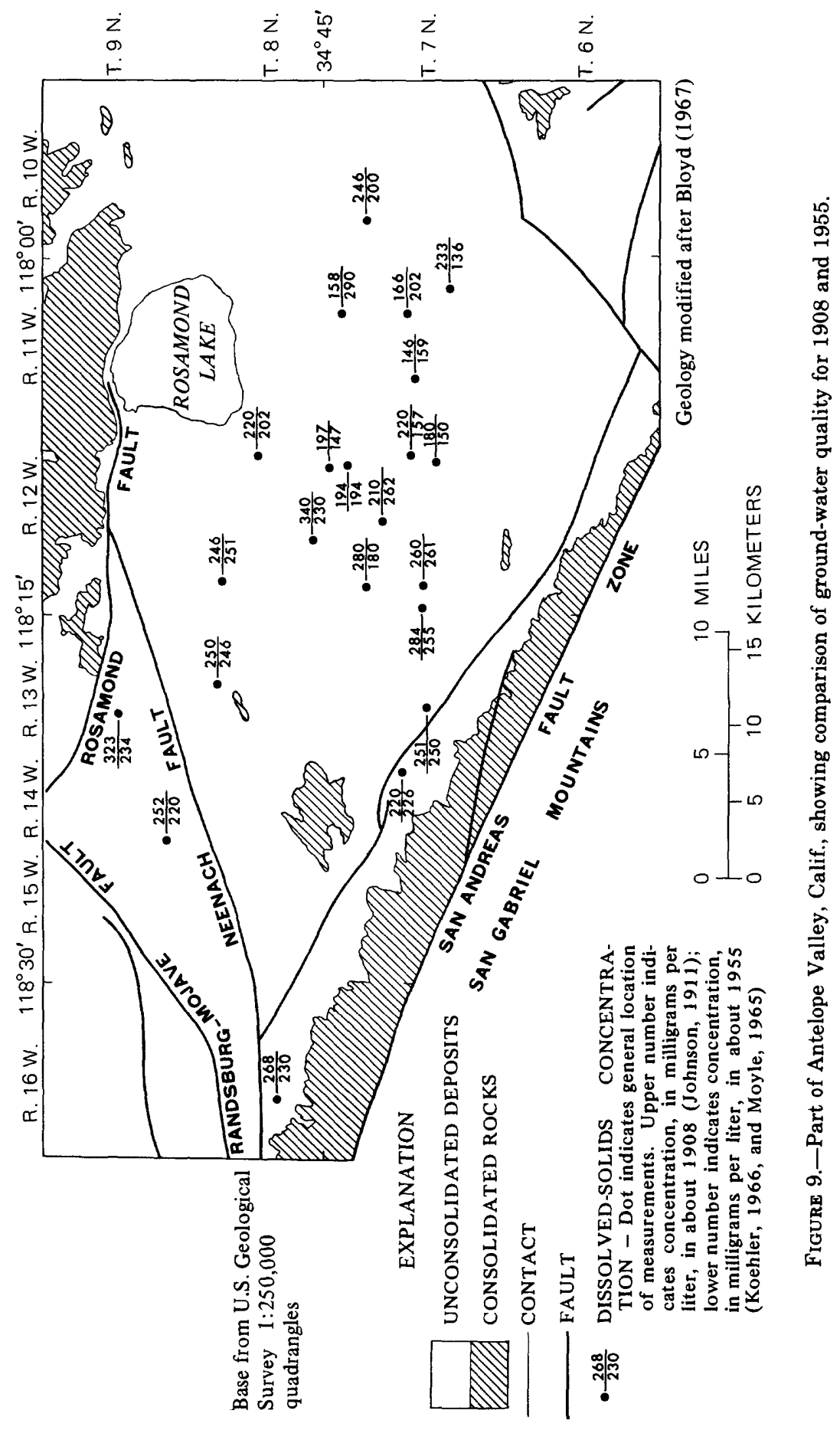




\section{SELECTION OF NET PUMPAGE FOR MODEL CALIBRATION}

The pumpage that is actually input to the model is the net pumpage, which is the quantity of water extracted from wells minus the quantity of irrigation return that reaches the water table. Significant uncertainty exists regarding both of these quantities, and a possible consequence of using the wrong net pumpage in the model calibration is storage-coefficient values that deviate from the true values. The following section describes the decision process used to select, from a limited number of alternatives, the net pumpage that probabilistically is nearest to the true net pumpage.

If the true state of the prototype were known, the consequence of using a given net pumpage could be determined. Under uncertainty, however, the consequence cannot be determined simply because the state of the prototype is not known for certain, and thus it is necessary to use the concept of expected value. The expected value of the consequences of a decision is the weighted sum of the consequences of the decision for the various states of nature. The weights are the probabilities that a particular state is realized in the prototype. For each net pumpage it is possible to compute the expected consequence, and the best decision is the decision with the smallest expected consequence. An index of the consequence of using a particular net pumpage is the deviation of the pumpage from the true pumpage. The best pumpage to use, then, is the one for which the expected value of the deviation is the least.

The possible pumpages are defined as $P_{1}$ and $P_{2}$, which symbolically represent pumpage curves $A$ and $B$ in figure 8 . The possible irrigation returns are defined as $R_{1}$ and $R_{2}$, which represent full irrigation return to the water table and no irrigation return. Thus, there are four possible joint states of the ground-water basin; $P_{1}$ can occur with either $R_{1}$ or $R_{2}$, and $P_{2}$ also can occur with either $R_{1}$ or $R_{2}$. For 1950 through 1961 the net pumpages $P_{1} R_{1}$ (where $P_{1} R_{1}$ symbolically represents the joint occurrence of $P_{1}$ and $R_{1}$ ) and $P_{2} R_{2}$ are about equivalent because $P_{1}$ equals about 1.4 $P_{2} . P_{1}$ and $P_{2}$ are assumed to be equally likely true states of the prototype. Similarly, $R_{1}$ and $R_{2}$ are assumed to be equally likely true states of the prototype. It follows, if the pumpage and irrigation states occur independently, the joint occurrence of any of the possible combinations of pumpage and irrigation return is equal to one-fourth.

A way of presenting decisionmaking problems involves the use of tree diagrams. In figure 10 a tree diagram for the selection of the net pumpage to use in the calibration of the model is presented. The point at the left-hand node of the diagram represents the initial position, and the four branches of the tree emanating from that point represent the four decisions in the problem. Thus, the left-hand fork is called a 


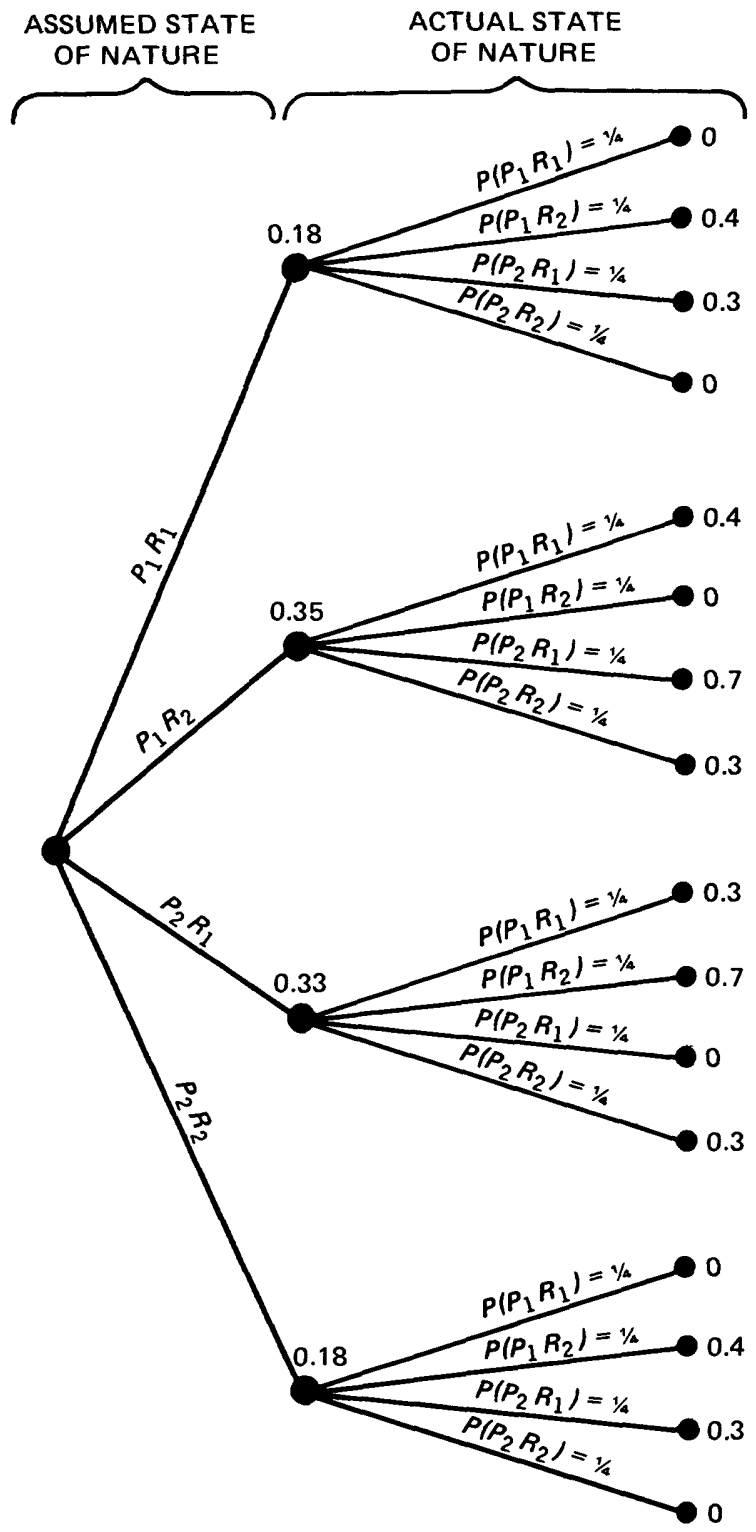

Figure 10.-Decision tree showing selection of net pumpage for calibration of transient-state model.

decision fork. At the end of each of the four branches representing the possible decisions, there is another fork with four branches. These four branches represent the possible states of the ground-water basin, and these forks are called state forks. 
The numbers on the state branches are the probabilities of the states. The numbers on the right-hand side of the tree diagram are the relative deviations of the assumed net pumpage from the true net pumpage under the realization of a particular state. For example, if the decision is taken to use net pumpage $P_{1} R_{1}$ in the model calibration, but the true state of the prototype is net pumpage $P_{1} R_{2}$, the consequence is the deviation of assumed pumpage from the actual pumpage by the relative amount 0.4 . The numbers at the state forks are the expected values of the deviation.

At the decision fork, the net pumpages $P_{1} R_{1}$ and $P_{2} R_{2}$ have the lowest expected deviation. Pumpage $P_{1} R_{1}$ represents pumpage curve $A$ in figure 8 combined with an irrigation return equal to 30 percent of the pumpage. Pumpage $P_{2} R_{2}$ represents pumpage curve $B$ in figure 8 combined with no irrigation return.

The above analysis applies only for 1950 through 1961 . The results of a similar analysis for 1915 through 1949 indicate that all the net pumpages have equal expected deviations. If the probability of no irrigation return during 1915 through 1949 is greater than one-half, however, which would be a reasonable assumption given the assumption of equal likelihood for 1950 through 1961, the decision analysis indicates that net pumpages $P_{1} R_{2}$ and $P_{2} R_{2}$ (which are similar net pumpages because curves $A$ and $B$ in figure 8 coincide for much of the period 1915 through 1949) produce the smallest expected deviation of the assumed pumpage from the true pumpage.

The equal likelihood for all possible states was assumed in the analysis. $P_{2}$ is probably a more likely state of the prototype than $P_{1}$, however. Likewise, $R_{2}$ is probably a more likely state than $R_{1}$. The revision of the analysis with probabilities reflecting these subjective evaluations clearly indicates the use of net pumpage $P_{2} R_{2}$ in the calibration of the transient-state model. This net pumpage was in fact used.

\section{REDUCTION OF NATURAL DISCHARGE}

Natural discharge of ground water by evapotranspiration is greatest if the water table is near the land surface. If the position of the water table moves downward, the rate of natural discharge is suppressed. If the water table moves beyond the reach of roots of plants, natural discharge by evapotranspiration will become insignificant.

Pumping from the Antelope Valley ground-water basin has caused lowering of the water table and, consequently, the suppression of natural discharge. Field data are not available on the effects of water-level declines on the level of natural discharge, but operation of the model indicates that this discharge may have ceased in about 1950 (fig. 11). The mass balance for the Antelope Valley ground- 


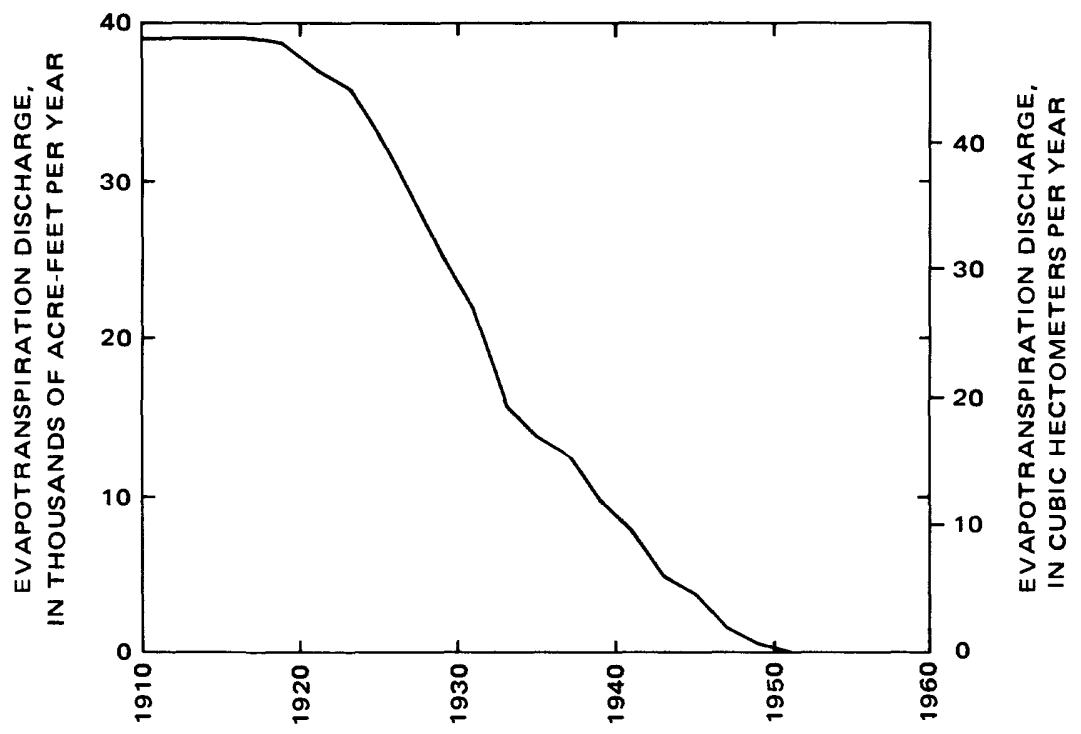

Figure 11.-Reduction of evapotranspiration computed by the mathematical model.

water basin indicates that the annual discharge of ground water by evapotranspiration may have been about 39,400 acre-ft $\left(48.5 \mathrm{hm}^{3}\right)$ in 1915.

Theoretical research on the discharge of ground water by evapotranspiration has been restricted to determining the annual use of water by different plant species when the depth to the water table does not change greatly with time. Very little is known about the quantitative effects of large temporal changes in the depth to the water table. Prediction of changes in the use of ground water is difficult because roots of established plants may, to a limited extent, keep pace with a declining water table, especially if the depth to the water table increases slowly. This phenomenon has not been quantified by researchers, however. Therefore, its possible occurrence was ignored in the construction of the model. The relation shown in figure 3 was assumed to relate temporal changes in evapotranspiration discharge to temporal changes in the depth to the water table, even though the relation shown in figure 3 actually applies only to the case of a time-invariant depth to the water table.

\section{CALIBRATION OF THE TRANSIENT-STATE MODEL}

The transient-state model was calibrated to the prototype water levels for 1961 . Hydraulic heads that were computed for 1915 by the mathematical model were used as initial conditions, and the model simulated changes in hydraulic heads for 1915 through 1961. For 
operation of the model, this period was divided into 235 time steps, each of 73 days. The pumpage for a given year (fig. 7) was assumed to be distributed uniformly throughout the year.

Even though a large number of water-level observations are available (Dutcher and others, 1962; Moyle, 1965; Koehler, 1966), accurate potentiometric maps of the principal and deep aquifers cannot be constructed from field data. Intraaquifer confining members occur in both the principal and deep aquifers (a condition that was not considered in the conceptual model), and differential pumping from between these members has caused the development of vertical hydraulichead differentials within the aquifers. Head differentials of as much as $80 \mathrm{ft}(24 \mathrm{~m})$ in places occur over a vertical interval as small as 400 $\mathrm{ft}(120 \mathrm{~m})$. In the principal aquifer, the heads in shallow wells are typically higher than heads in deeper wells; however, in some areas this situation is reversed. Consequently, the indicated head at a point in the potentiometric map (pl. 3) is intended to represent the average head over the saturated thickness of the aquifer at that point.

The calibration procedure was started by making initial estimates of the storage coefficient of the principal and deep aquifers. Using lithologic logs for wells, geologic data, and laboratory tests of similar deposits, Bloyd (1967) estimated the storage coefficient of the principal aquifer and of the deep aquifer for areas where the deep aquifer is unconfined. For the applicable areas these estimates were used as initial estimates of the storage coefficient in the calibration procedure. In the area where the deep aquifer is confined, the storage coefficient of the deep aquifer was estimated by using the rule of thumb that the ratio of the storage coefficient to the aquifer thickness is about $10^{-6}$ per foot $\left(3 \times 10^{-6}\right.$ per meter) (Lohman, 1972). The average thickness of the aquifer in the confined area is about $1,000 \mathrm{ft}$ $(300 \mathrm{~m})$, and a storage coefficient of 0.001 for this area was used in the model.

The transmissivity of the principal and deep aquifers and the vertical hydraulic conductivity of the lacustrine deposits were obtained from the calibration of the steady-state model and were used in the transient-state model. These parameters were invariant during the calibration of the transient-state model; hence, the objective of this calibration was to fit the transient-state model to the prototype water levels by adjusting the storage coefficient. Only the storage coefficients of the principal aquifer and of the deep aquifer where it is unconfined were adjusted during the calibration.

Plates 11 and 12 show the final storage coefficients for the principal and deep aquifers. The storage coefficients do not deviate significantly from the initial estimates (fig. 4).

Hydrographs of computed hydraulic heads and measured water levels in the principal aquifer are shown in figures 12 and 13. The 


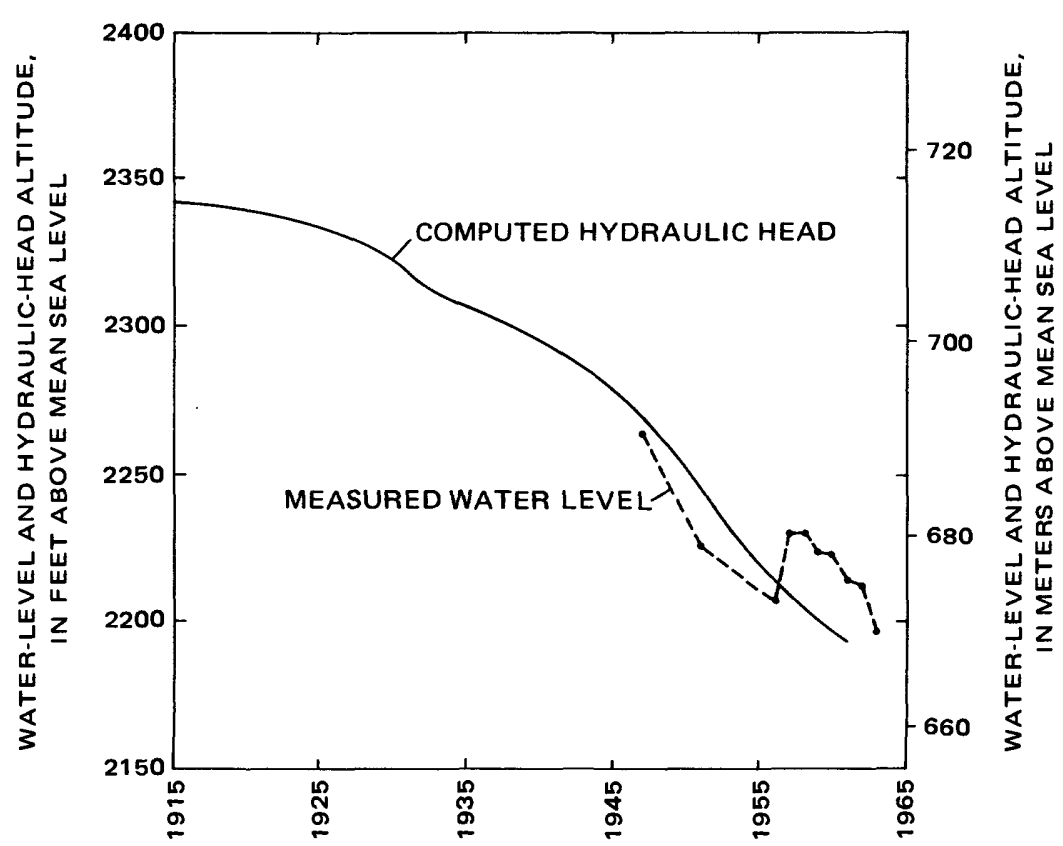

FIGURE 12.-Hydrographs of computed hydraulic heads in the principal aquifer at node 144 and measured water levels in well $8 \mathrm{~N} / 13 \mathrm{~W}-11 \mathrm{Q} 1$. Water-level measurements are from Moyle (1965).

hydraulic heads were computed by the mathematical model using the storage-coefficient distributions given on plates 11 and 12 and the transmissivity distributions given on plates 7 and 8 . Plate 13 shows the geographic variation of hydraulic heads in the principal and deep aquifers that were computed by the mathematical model. The general shape of the computed solution compares well with the potentiometric map of the prototype water levels shown on plate 3 ; however, the areas of low hydraulic head that are associated with areas of concentrated pumpage are more disperse in the computed solution than those observed in the prototype. Considering all areas of the ground-water basin, the area-weighted median absolute deviation of the computed hydraulic heads from the prototype water levels was 25 $\mathrm{ft}(7.6 \mathrm{~m})$ (fig. 5).

\section{DESCRIPTION OF MODELING ERRORS}

\section{SOURCES OF ERROR}

The observed deviation of the computed hydraulic heads from the prototype water levels is the result of errors associated with the conceptual model, the computational scheme, the system parameters, the 


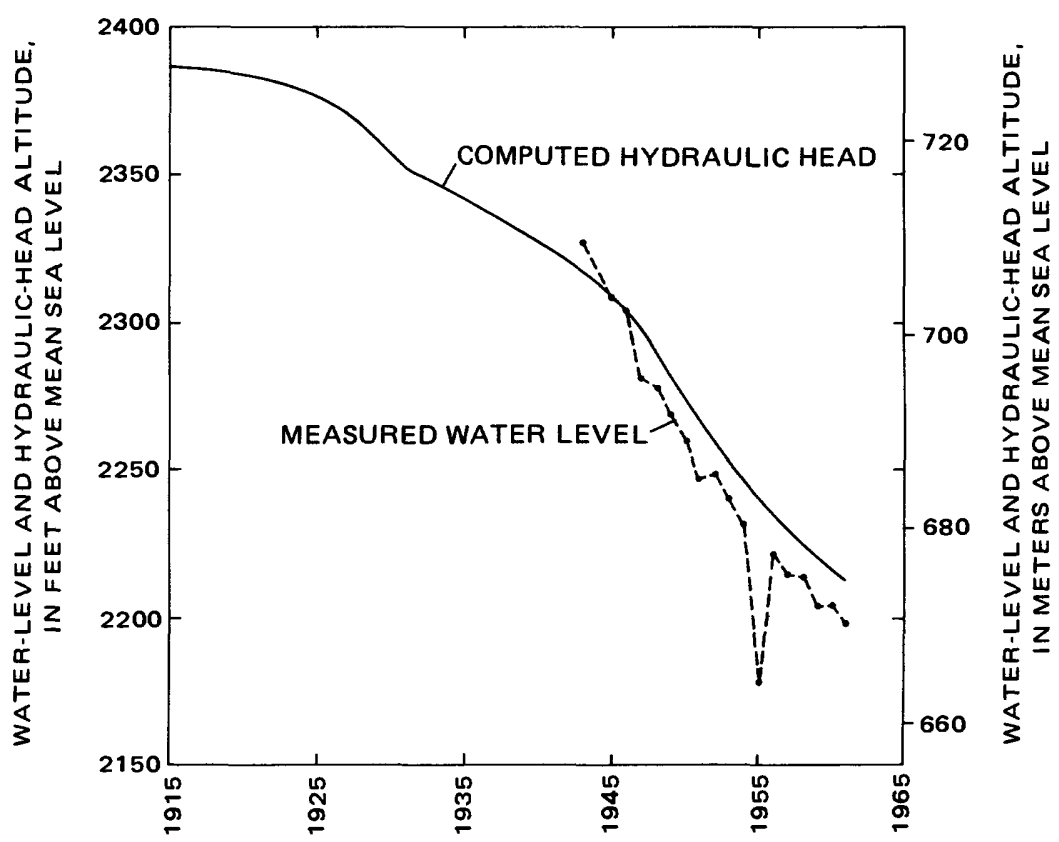

FIGURE 13.-Hydrographs of computed hydraulic heads in the principal aquifer at node 248 and measured water levels in well $7 \mathrm{~N} / 11 \mathrm{~W}-28 \mathrm{E} 1$. Water-level measurements are from Koehler (1966).

input data, the initial conditions, and the prototype water levels. Table 2 gives a subjective assessment of the relative importance of these sources of error in explaining the observed deviations.

TABLE 2.-Importance of various possible sources of the deviation of the computed water levels from the prototype water levels

\begin{tabular}{|c|c|c|}
\hline \multirow{2}{*}{ Source of error } & \multicolumn{2}{|c|}{ Relative Importance } \\
\hline & Steady-state model & Transient-state model \\
\hline $\begin{array}{l}\text { Conceptual model } \\
\text { Computational scheme } \\
\text { System parameters } \\
\text { Input data } \\
\text { Initial conditions } \\
\text { Prototype water levels }\end{array}$ & $\begin{array}{l}\text { Low } \\
\text { Low } \\
\text { Low } \\
\text { Intermediate } \\
\text { None } \\
\text { High }\end{array}$ & $\begin{array}{l}\text { Intermediate } \\
\text { Low } \\
\text { Low } \\
\text { High } \\
\text { Intermediate } \\
\text { High }\end{array}$ \\
\hline
\end{tabular}

\section{Conceptual model}

The errors associated with the conceptual model are errors that result mainly from the simplifying assumptions used in the conceptualization of the prototype. Although errors of conceptualization are probably not large compared to other errors in the model, these errors result mostly from the assumption that intraaquifer ground-water 
flow is strictly horizontal and that the transmissivity of the principal aquifer is time invariant.

\section{Computational scheme}

Errors associated with the computational scheme are errors resulting from the numerical approximation of the solution to the governing equations. The numerical solution converges to the true solution as the elements are reduced to zero area (Hutton and Anderson, 1971). The use of elements with nonzero area results in the departure of the numerical solution from the true solution, especially where large changes in hydraulic-head gradients are involved. The computation scheme is not a serious source of error in the model, however.

\section{System parameters}

The system parameters consist of the transmissivity and storage coefficient of the principal and deep aquifers and the vertical hydraulic conductivity of the lacustrine deposits. Prior estimates of these parameters are refined during the calibration of the model. The objective of the calibration is to identify parameter values that minimize the deviation of the computed hydraulic heads from the measured water levels while keeping the parameter values within physically reasonable limits. It is difficult to recognize when minimum-deviation parameter values have been found, however, and the calibration procedure is usually terminated prematurely. The presumption always remains that, if additional calibration runs had been made, perhaps the fit of the model to the prototype water levels could have been improved.

In using the model to make predictions of the response of the prototype to specified inputs, errors associated with the system parameters result from the deviation of the system parameters from their true values. Relatively small adjustments were made to the system parameters during the calibration of the steady-state and transientstate models. A consistency exists between estimates of the system parameters obtained from field data and estimates obtained from the calibration procedures. Consequently, the probability that the system parameters used in the model are close to the true parameters is greater than if that consistency did not exist.

Nevertheless, uncertainty as to the actual pumpage and irrigation return creates a corresponding uncertainty as to the adequacy of the storage-coefficient values obtained from the calibration of the transient-state model. Although not previously discussed, the actual natural recharge to the ground-water basin is known uncertainly, which creates uncertainty as to the adequacy of the transmissivity values obtained from the calibration of the steady-state model. 
If different estimates of the state of the prototype had been used in the calibration, different estimates of the system parameters probably would have been obtained. Figures 14 and 15 show the effects that changes in the system parameters would have on the predictions of hydraulic head that are made with the model. Figure 14 shows the effects on the computed hydraulic heads of relative changes in the storage-coefficient values. The measure of the effect on the computed hydraulic heads is the relative deviation of the computed changes in hydraulic heads at the end of a 20-year simulation period. The maximum and the median deviation are indicated in figure 14. Correspondingly, figure 15 shows the effects on computed hydraulic heads of relative changes in the transmissivity values.

The maximum relative deviation is quite sensitive to changes in the system parameters. The maximum relative deviation, however, is

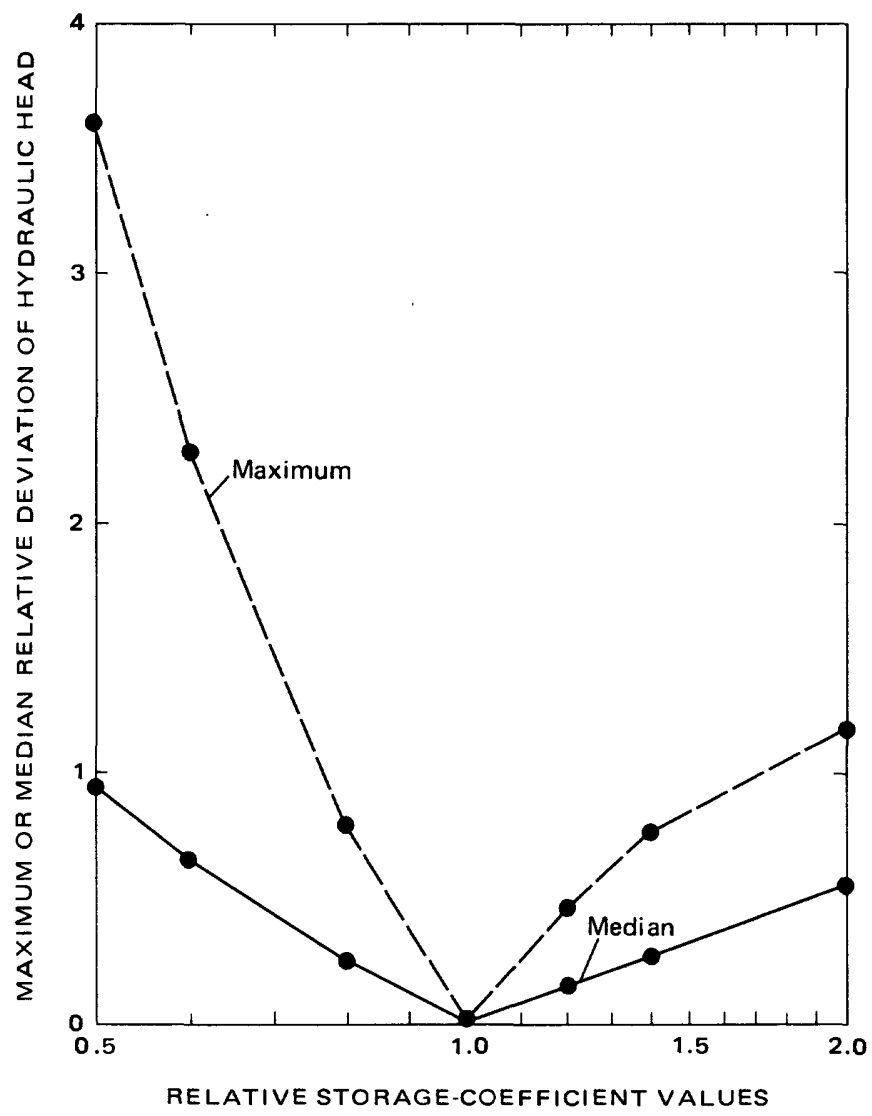

FIgURE 14.-Sensitivity of computed hydraulic heads to changes in the storage-coefficient values used in the model. 


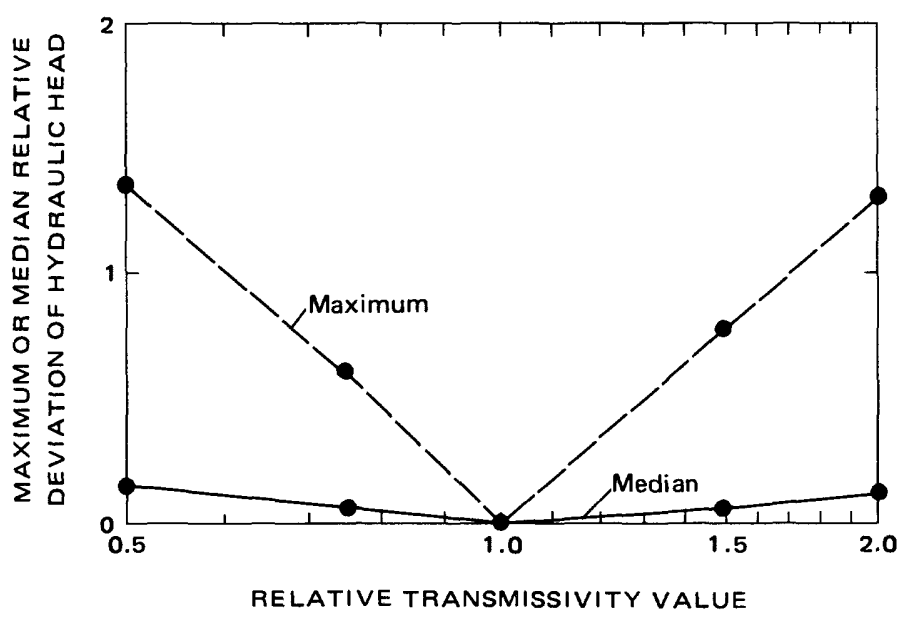

FIGURE 15.-Sensitivity of computed hydraulic heads to changes in the transmissivity values used in the model.

generally associated with areas that have smaller head changes. The median deviation is less sensitive to changes in the system parameters than is the maximum deviation. This is especially true for changes in transmissivity.

\section{Input data}

Errors associated with the input data are errors that result from the estimation of natural recharge, natural discharge, pumpage, and irrigation return. Techniques used to obtain these estimates typically bias the estimates, and the bias is for the most part transferred to the system parameters during the calibration process. This may be a relatively important error source.

\section{Initial conditions}

Operation of the transient-state model requires specification of initial hydraulic heads. Errors in the initial hydraulic heads produce errors in the computed hydraulic heads. In general, however, these errors become less important as the duration of the period of simulation increases.

\section{Prototype water levels}

Errors associated with the prototype water levels are errors of measurement, sampling, and interpretation. The largest errors of measurement probably result from locating wells incorrectly and thereby incorrectly estimating the altitude of the land surface at the well from topographic maps. Some water-level measurements may not be 
representative of the aquifer. Measurement of water levels in wells that are being affected by local pumping or in wells tapping perched water bodies, for example, will not be representative of aquifer conditions. These are sampling errors. Interpretation errors arise where field data are contoured or extrapolated to areas without any data. Prototype water levels probably are a serious error source.

\section{ERRORS OF PREDICTION}

The predictive accuracy of the model, when measured in terms of the deviation of the computed hydraulic heads from the prototype water levels, is directly proportional to the magnitude and duration of pumping. The greater the pumpage or the longer the duration of pumping, the greater will be the probable errors in computed hydraulic heads. If the future magnitude and duration of pumping are similar to those used in the calibration of the transient-state model, the deviation of the computed hydraulic heads from the prototype water levels that were obtained from the calibration of the transientstate model is probably indicative of the predictive accuracy of the model. It may be possible, however, to improve the predictive accuracy of the model by selective use.

Consider three questions that can be asked about model predictions:

1. What will be the future pumpage and what will be the response of the prototype to that pumpage?

2. What will be the response of the prototype to any specified pumpage?

3 . What will be the differential response of the prototype to two specified pumpages that are defined to be mutually exclusive?

The answer to the first question will contain errors that result from errors in the conceptual model, errors in the system parameters, errors in the initial conditions, and errors in the pumpage. The answer to the second question, however, will not contain errors resulting from errors in the pumpage. The third question eliminates initial conditions from consideration, and the answer to this question will not contain errors that result from either pumpage or initial conditions.

The elimination of pumpage errors from the second question will improve the probable accuracy of the answer to this question relative to the accuracy of the answer to the first question. The additional elimination of initial-condition errors from the third question will improve the probable accuracy of the answer to this question relative to the accuracy of the answers to both the first and second questions. Therefore, the best predictions are made with the model for interrogations involving the differential response of the prototype. 


\section{NUMERICAL SOLUTION OF THE GROUND-WATER EQUATIONS}

THE GALERKIN-FINITE ELEMENT CONCEPT

To solve numerically the governing equations of ground-water flow, the solution is expressed by a finite number of parameters. Secondly, we transform the equations of ground-water flow into expressions
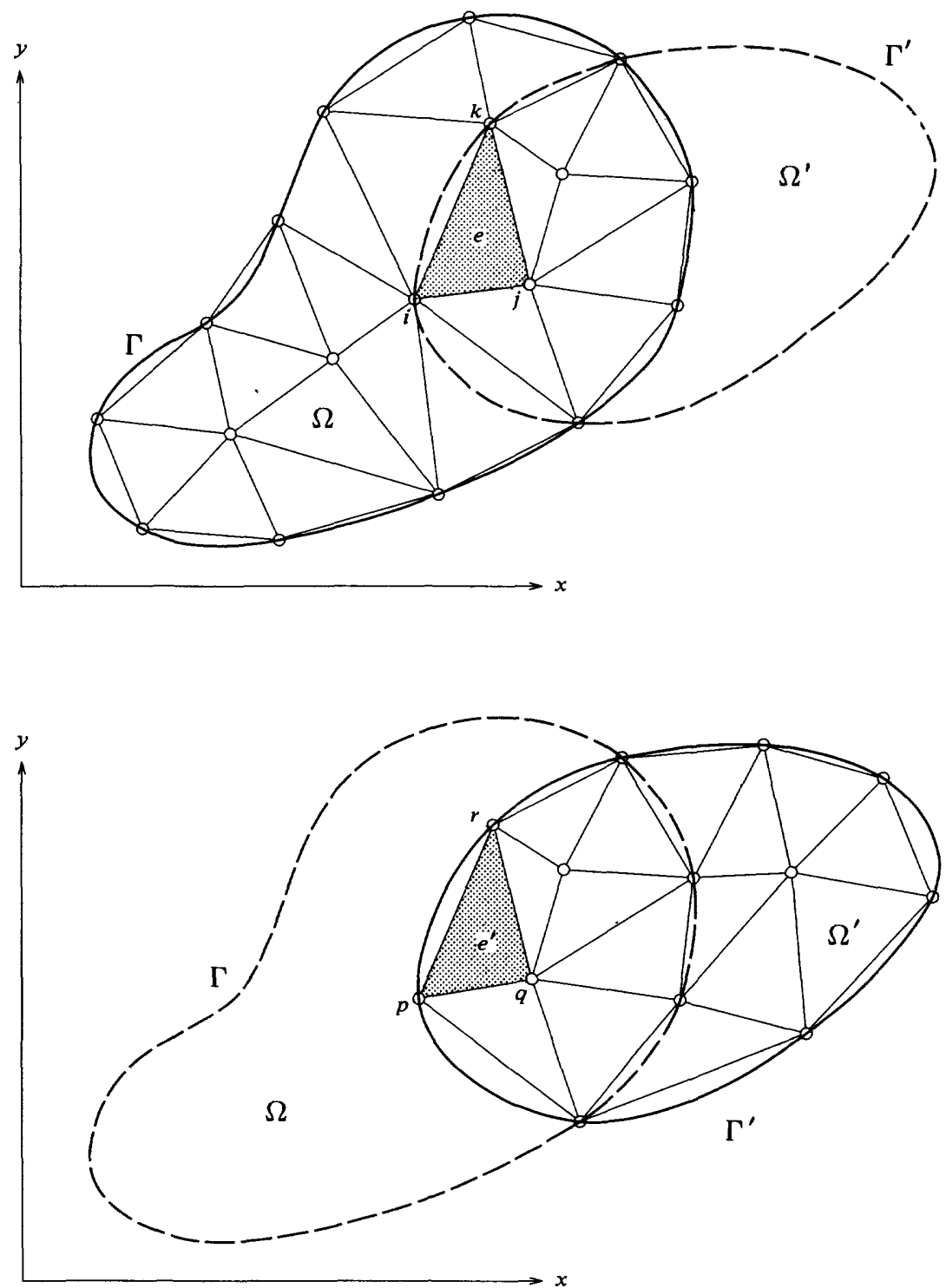

Figure 16.-Finite-element discretization scheme used in the mathematical model. 
relating these parameters. If the equations are linear, then the relations among the parameters expressing the solution are also linear, that is, we are led to a linear system of algebraic equations. In this process we cannot avoid dealing with a large system of equations. To ameliorate this situation, it is necessary to choose the parameters in such a way that the resulting coefficient matrix is sparse. One method reflecting this feature is the Galerkin-finite element method.

The Galerkin-finite element method was applied to the analysis of single-aquifer ground-water systems by Pinder and Frind (1972). Extension of the Galerkin-finite element method to the analysis of twoaquifer ground-water systems follows. Development of the solution scheme for this system follows the development presented by Pinder and Frind (1972). The difference between their approach and the approach used here results from the selection of a different element shape and the application of the method to a two-aquifer system.

The fundamental idea of the Galerkin-finite element method is to replace a continuous function by values of the function that are specified at a finite number of discrete points called nodes. Function values between these points are calculated using piecewise continuous interpolating functions defined over a finite number of subdomains called elements.

Consider a two-aquifer ground-water system. The first aquifer includes the domain $\Omega$, which is surrounded by the boundary $\Gamma$. The second aquifer includes the domain $\Omega^{\prime}$, which is surrounded by the boundary $\Gamma^{\prime}$. The subdivision of this system into triangular elements is shown schematically in figure 16 . The domains $\Omega$ and $\Omega^{\prime}$ are not everywhere coincident; however, in the areas where these domains are coincident, the elements are also coincident, that is, the nodes $i, j$, and $k$ respectively have the same locations in the $x-y$ plane as the nodes $p, q$, and $r$. The discussion that follows is based in part on the above characteristics of the layout of nodes and elements.

\section{GALERKIN APPROXIMATION}

Let us define the linear operators $L$ and $L^{\prime}$ as

$$
\begin{aligned}
L(h) \equiv \frac{\partial}{\partial x}\left(T \frac{\partial h}{\partial x}\right)+\frac{\partial}{\partial y}\left(T \frac{\partial h}{\partial y}\right) & -S \frac{\partial h}{\partial t} \\
& -W-\frac{K}{b}\left(h-h^{\prime}\right)=0
\end{aligned}
$$

and 


$$
\begin{aligned}
L^{\prime}\left(h^{\prime}\right) \equiv \frac{\partial}{\partial x}\left(T^{\prime} \frac{\partial h^{\prime}}{\partial x}\right)+\frac{\partial}{\partial y}\left(T^{\prime} \frac{\partial h^{\prime}}{\partial y}\right)-S^{\prime} \frac{\partial h^{\prime}}{\partial t} \\
-W^{\prime}-\frac{K}{b}\left(h^{\prime}-h\right)=0,
\end{aligned}
$$

where $x, y$ are cartesian coordinates,

$T$ is the transmissivity of the first aquifer,

$S$ is the storage coefficient of the first aquifer,

$W$ is the flux of a source or sink in the first aquifer,

$h$ is the head in the first aquifer,

$K$ is the vertical hydraulic conductivity of the confining layer,

$b$ is the thickness of the confining layer,

$T^{\prime}$ is the transmissivity of the second aquifer,

$S^{\prime}$ is the storage coefficient of the second aquifer,

$W^{\prime}$ is the flux of a source or sink in the second aquifer, and

$h^{\prime}$ is the head in the second aquifer.

Equations 5 and 6 are to be solved in domains $\Omega$ and $\Omega^{\prime}$, which are enclosed by the boundaries $\Gamma$ and $\Gamma^{\prime}$. The boundary conditions are

$$
\frac{\partial h}{\partial n}=0 \text { on } \Gamma
$$

and

$$
\frac{\partial h^{\prime}}{\partial n}=0 \text { on } \Gamma^{\prime},
$$

where $\delta / \delta n$ is the outward-pointing normal derivative on $\Gamma$ and $\Gamma^{\prime}$.

To solve $L(h)=0$ and $L^{\prime}\left(h^{\prime}\right)=0$, we assume trial solutions of the forms

and

$$
h(x, y, t) \simeq \hat{h}(x, y, t)=\sum_{i=1}^{n} C_{i}(t) \phi_{i}(x, y)
$$

$$
h^{\prime}(x, y, t) \simeq \hat{h}^{\prime}(x, y, t)=\sum_{i=1}^{n^{\prime}} C_{i}^{\prime}(t) \phi^{\prime}{ }_{i}(x, y),
$$

where $\hat{h}$ and $\hat{h}^{\prime}$ are series approximations to $h$ and $h^{\prime} ; \phi i$ and $\phi^{\prime} i$ are linearly independent trial functions defined over the domains $\Omega$ and $\Omega^{\prime}$ and are chosen beforehand. $C_{i}$ and $C^{\prime}{ }_{i}$ are undetermined coefficients, and $n$ and $n^{\prime}$ are the number of nodal points.

The Galerkin-finite element approximation to equation 5 only will be considered. (It will be shown later how the simultaneous solution to both equations 5 and 6 can be obtained.)

The series approximation to equation 5 will provide an exact representation as $n$ approaches infinity (Forray, 1968, p. 191). For a finite series, the approximation will not exactly satisfy equation 5 , and there will be a residual $R$. The residual is defined by 


$$
R(x, y, t)=L\left[\sum_{i=1}^{n} C_{i}(t) \phi_{i}(x, y)\right] .
$$

If the trial solution were the exact solution, the residual would vanish. We attempt to force this residual to zero, in an average sense, through our selection of the undetermined coefficients $C_{i}$.

The $C_{i}$ are calculated by setting the weighted integrals of the residuals to zero. In the Galerkin method (Galerkin, 1915), trial functions are used as weighting functions, that is,

$$
\iint_{\Omega} L\left[\sum_{j=1}^{n} C_{j}(t) \phi_{j}(x, y)\right] \phi_{i}(x, y) d x d y=0 .
$$

From equation 12 we obtain $n$ linear equations, which can be solved for the $n$ values of $C_{j}$.

First, equation 12 can be simplified. By expanding equation 12 we obtain

$$
\begin{gathered}
\iint_{\Omega}\left[\frac{\partial}{\partial x}\left(T \frac{\partial}{\partial x} \sum_{j=1}^{n} C_{j} \phi_{j}\right)+\frac{\partial}{\partial y}\left(T \frac{\partial}{\partial y} \sum_{j=1}^{n} C_{j} \phi_{j}\right)-S \frac{\partial}{\partial t} \sum_{j=1}^{n} C_{j} \phi_{j}\right. \\
\left.-W-\frac{K}{b}\left(h^{\prime}-\sum_{j=1}^{n} C_{j} \phi_{j}\right)\right] \phi_{i} d x d y=0 \\
i=1,2, \ldots, n
\end{gathered}
$$

The quantity $h^{\prime}$, which occurs in the leakage term of equation 13 , can be replaced by the trial solution for $h^{\prime}$. By making this substitution into equation 13 we obtain

$$
\begin{gathered}
\iint_{\Omega}\left[\frac{\partial}{\partial x}\left(T \frac{\partial}{\partial x} \sum_{j=1}^{n} C_{j} \phi_{j}\right)+\frac{\partial}{\partial y}\left(T \frac{\partial}{\partial y} \sum_{j=1}^{n} C_{j} \phi_{j}\right)-S \frac{\partial}{\partial t} \sum_{j=1}^{n} C_{j} \phi_{j}\right. \\
\left.-W-\frac{K}{b}\left(\sum_{j=1}^{n^{\prime}} C_{j}^{\prime} \phi_{j}^{\prime}-\sum_{j=1}^{n} C_{j} \phi_{j}\right)\right] \phi_{i} d x d y=0 \\
i=1,2, \ldots, n
\end{gathered}
$$

Equation 14 can be integrated by parts. By assuming transmissivity to be constant over each element and recalling that $C_{j}$ is a function of time only, we obtain from integration by parts of equation 11 (Pinder and Frind, 1972) 


$$
\begin{gathered}
\iiint_{\Omega} \sum_{j=1}^{n}\left(T \frac{\partial \phi_{i}}{\partial x} \frac{\partial \phi_{j}}{\partial x}+T \frac{\partial \phi_{i}}{\partial y} \frac{\partial \phi_{j}}{\partial y}+\frac{K}{b} \phi_{i} \phi_{j}\right) C_{j} d x d y+ \\
\iint_{\Omega} S \phi_{i} \sum_{j=1}^{n} \phi_{j} \frac{d C_{j}}{\partial t} d x d y+\iint_{\Omega} \phi_{i} W d x d y-\iint_{\Omega} \phi_{i} \frac{K}{b} \sum_{j=1}^{n^{\prime}} C_{j}^{\prime} \phi_{j} d x d y- \\
\iint_{\Gamma} \sum_{j=1}^{n} T \frac{\partial \phi}{\partial n}{ }_{j} C_{j} d \Gamma=0,
\end{gathered}
$$

where $\delta / \partial n$ is the outward-pointing normal derivative on the boundary. Recall that this derivative is everywhere defined to equal zero (eq. 7); therefore, the term containing this derivative vanishes.

The $n$ equations of equation 15 can be written in matrix form as

$$
[A]\{C\}+[B]\left\{\frac{d C}{d t}\right\}+[D]\left\{C^{\prime}\right\}+\{F\}=0,
$$

where $[A]$ and $[B]$ are $n \times n$ dimensional matrices; $[D]$ is an $n \times n^{\prime}$ dimensional matrix; $\{C\},\{d C / d t\}$, and $\{F\}$ are $n$ dimensional vectors; and $\left\{C^{\prime}\right\}$ is an $n^{\prime}$ dimensional vector. Using terminology from structural engineering, $[A]$ is called the stiffness matrix, $[B]$ is called the dynamic matrix, and $\{F\}$ is called the force vector. The matrix $[D]$ will be called the leakage matrix.

Typical elements of $[A],[B],[D]$, and $\{F\}$ are

$$
\begin{aligned}
& A_{i j}=\iint_{\Omega}\left(T \frac{\partial \phi_{i}}{\partial x} \frac{\partial \phi_{j}}{\partial x}+T \frac{\partial \phi_{i}}{\partial y} \frac{\partial \phi_{j}}{\partial y}+\frac{K}{b} \phi_{i} \phi_{j}\right) d x d y \\
& B_{i j}=\iint_{\Omega} S \phi_{i} \phi_{j} d x d y \\
& D_{i j}=-\iint_{\Omega} \phi_{i} \phi_{j} \frac{K}{b} d x d y \\
& F_{i}=\iint_{\Omega} \phi_{i} W d x d y .
\end{aligned}
$$


TRIAL FUNCTIONS

In order to generate the set of algebraic equations represented by equation 16 , it is necessary to perform integrations of the trial functions of the form

and

$$
\begin{aligned}
& \iint \frac{\partial \phi_{i}}{\partial x} \frac{\partial \phi_{j}}{\partial x} d x d y \\
& \iint \phi_{i} \phi_{j} d x d y \\
& \iint \phi_{i} d x d y
\end{aligned}
$$

The suitability of the Galerkin approximation for computer application depends on the selection of the trial functions, such that the computational effort for the integrations is minimized.

To facilitate these integrations, the trial functions are defined piecewise in the element sense to obtain global trial functions in the domain $\Omega$. Within an element the approximate solution (equation 9 ) can be expressed as

$$
\hat{h}(x, y)=\sum_{i=1}^{3} C_{i}(t) \omega_{i}^{e}(x, y),
$$

where $\omega_{i}^{e}$ represents local trial functions that are defined only within the element $e$.

The local trial functions used in this study are linear and are defined on triangular elements. The trial functions are defined such that $\omega_{i}^{e}$ are nonzero only over element $e$, equal to unity at the node $i$, and equal to zero at all other nodes. These functions for the node $i$ (fig. 17) are given by

$$
\omega_{i}^{e}(x, y)=\frac{1}{2 A}\left[\left(y_{j}-y_{k}\right) x+\left(x_{k}-x_{j}\right) y+\left(x_{i} y_{k}-x_{k} y_{j}\right)\right]
$$

for $(x, y)$ in element $e$; otherwise,

$$
\omega_{i}^{e}(x, y)=0,
$$

where $A$ represents the area of the element. Subscripts $i, j, k$ refer to the vertices of the triangular element, and the subscripts progress in counterclockwise order around the element. The area of the element is given by 


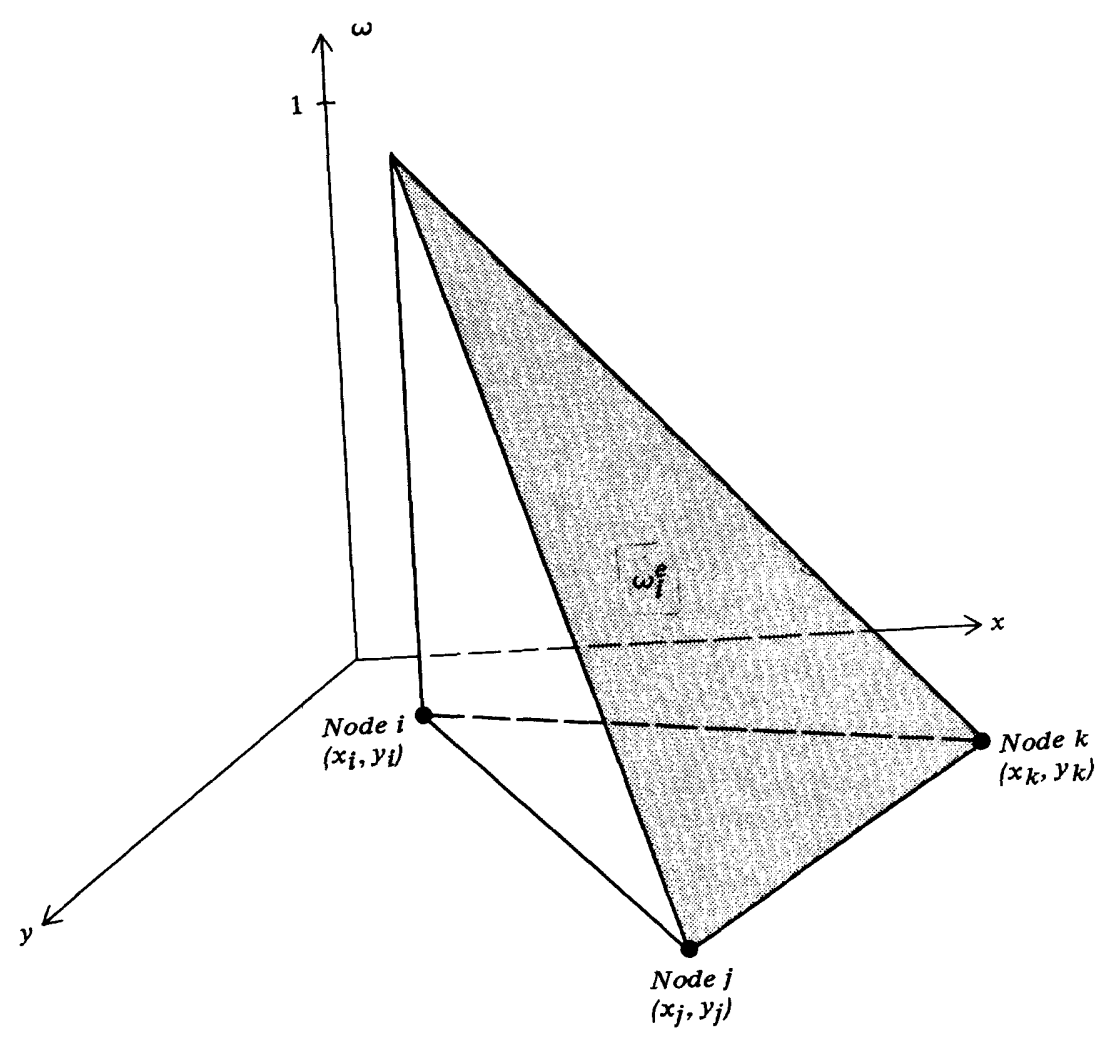

Figure 17.-Local trial function used in the mathematical model.

$$
A=\frac{1}{2}\left|\begin{array}{lll}
x_{i} & y_{i} & 1 \\
x_{j} & y_{j} & 1 \\
x_{k} & y_{k} & 1
\end{array}\right| .
$$

The global trial function $\phi_{i}$ is the union of those values of $\omega_{i}^{e}$ that are found to be nonzero at node $i$. Thus, the global trial functions are given by

$$
\phi_{i}(x, y)=\omega_{i}^{1} U \omega_{i}^{2} U \ldots U \omega_{i}^{k}
$$

where $\left\{\omega_{i}^{1}, \omega_{i}^{2}, \ldots, \omega_{i}^{k}\right\}$ is the set of all local trial functions that are nonzero at the node $i$.

An examination of equation 15 indicates that about $4 n^{2}$ integrations are required. Because the integrals have nonzero values only 
where two trial functions share the same element, the number of integrations that actually must be evaluated is much smaller.

\section{INTEGRATION OF THE APPROXIMATING EQUATION}

The integrations in equations $17,18,19$, and 20 are most easily performed on an element basis. Element matrices are generated, and the information is then transferred to the global matrix. Because there are three nodes in an element, each element matrix will be of order three.

Stiffness matrix.

A typical element stiffness matrix $[a]$ will be of the form

$$
\begin{gathered}
{[a]=T \iint\left[\begin{array}{lll}
\frac{\partial \omega_{1}}{\partial x} \frac{\partial \omega_{1}}{\partial x} & \frac{\partial \omega_{1}}{\partial x} \frac{\partial \omega_{2}}{\partial x} & \frac{\partial \omega_{1}}{\partial x} \frac{\partial \omega_{3}}{\partial x} \\
\frac{\partial \omega_{2}}{\partial x} \frac{\partial \omega_{1}}{\partial x} & \frac{\partial \omega_{2}}{\partial x} \frac{\partial \omega_{2}}{\partial x} & \frac{\partial \omega_{2}}{\partial x} \frac{\partial \omega_{3}}{\partial x} \\
\frac{\partial \omega_{3}}{\partial x} \frac{\partial \omega_{1}}{\partial x} & \frac{\partial \omega_{3}}{\partial x} \frac{\partial \omega_{2}}{\partial x} & \frac{\partial \omega_{3}}{\partial x} \frac{\partial \omega_{3}}{\partial x}
\end{array}\right] d x d y} \\
+T \int\left[\begin{array}{lll}
\frac{\partial \omega_{1}}{\partial y} \frac{\partial \omega_{1}}{\partial y} & \frac{\partial \omega_{1}}{\partial y} \frac{\partial \omega_{2}}{\partial y} & \frac{\partial \omega_{1}}{\partial y} \frac{\partial \omega_{3}}{\partial y} \\
\frac{\partial \omega_{2}}{\partial y} \frac{\partial \omega_{1}}{\partial y} & \frac{\partial \omega_{2}}{\partial y} \frac{\partial \omega_{2}}{\partial y} & \frac{\partial \omega_{2}}{\partial y} \frac{\partial \omega_{3}}{\partial y} \\
\frac{\partial \omega_{3}}{\partial y} \frac{\partial \omega_{1}}{\partial y} & \frac{\partial \omega_{3}}{\partial y} \frac{\partial \omega_{2}}{\partial y} & \frac{\partial \omega_{3}}{\partial y} \frac{\partial \omega_{3}}{\partial y}
\end{array}\right] d x d y \\
+\frac{K}{b} \iint\left[\begin{array}{lll}
\omega_{1} \omega_{1} & \omega_{1} \omega_{2} & \omega_{1} \omega_{3} \\
\omega_{2} \omega_{1} & \omega_{2} \omega_{3} & \omega_{2} \omega_{3} \\
\omega_{3} \omega_{1} & \omega_{3} \omega_{2} & \omega_{3} \omega_{3}
\end{array}\right] d x d y .
\end{gathered}
$$

Aquifer parameters that appear in the stiffness matrix are assumed to be constant over an element. Because the integration is performed over an element, these parameters are moved from under the integration. The indices used in the element stiffness matrix are local, and they pertain to nodes numbered counterclockwise around the triangle.

The integrations in equation 25 are performed in the global coordinate system. The following integration formulas are used:

$$
\begin{array}{r}
\iint \frac{\partial \omega_{i}}{\partial x} \frac{\partial \omega_{r}}{\partial x} d x d y=\frac{1}{4 A}\left(y_{r+1}-y_{r+2}\right)\left(y_{j}-y_{k}\right) \\
r=i, j, k
\end{array}
$$




$$
\begin{aligned}
\iint \frac{\partial \omega_{i}}{\partial y} \frac{\partial \omega_{r}}{\partial y} d x d y & =\frac{1}{4 A}\left(x_{r+2}-x_{r+1}\right)\left(x_{k}-x_{j}\right) \\
r=i, j, k & \\
\iint \omega_{i} \omega_{i} d x d y & =\frac{1}{6} A \\
\iint \omega_{i} \omega_{r} d x d y & =\frac{1}{12} A,
\end{aligned}
$$

where $x_{i}$ and $y_{i}$ are the coordinates of the node $i$.

The global stiffness matrix is obtained by summing, for a given global node, the contribution to that node from each element stiffness matrix. For example, if nodes $i$ and $j$ in the element nodal system correspond to nodes $p$ and $q$ in the global nodal system, the $a_{i j}$ in the element stiffness matrix is added to $A_{p q}$ in the global stiffness matrix. This operational procedure is repeated for each node in an element and for all elements in the domain $\Omega$.

\section{Dynamic matrix.}

A typical element dynamic matrix $[b]$ will be of the form

$$
[b]=S \iint\left[\begin{array}{lll}
\omega_{1} \omega_{1} & \omega_{1} \omega_{2} & \omega_{1} \omega_{3} \\
\omega_{2} \omega_{1} & \omega_{2} \omega_{2} & \omega_{2} \omega_{3} \\
\omega_{3} \omega_{1} & \omega_{3} \omega_{2} & \omega_{3} \omega_{3}
\end{array}\right] d x d y
$$

The integrals are evaluated using equations 28 and 29 , and the global dynamic matrix is assembled according to the operation procedure described previously.

Leakage matrix.

A typical element leakage matrix $[d]$ will be of the form

$$
[d]=\frac{K}{b} \iint\left[\begin{array}{lll}
\omega_{1} \omega_{1} & \omega_{1} \omega_{2} & \omega_{1} \omega_{3} \\
\omega_{2} \omega_{1} & \omega_{2} \omega_{2} & \omega_{2} \omega_{3} \\
\omega_{3} \omega_{1} & \omega_{3} \omega_{2} & \omega_{3} \omega_{3}
\end{array}\right] d x d y
$$

As we did for the element dynamic matrix, the integrals in the element leakage matrix are evaluated using equations 28 and 29; however, the assembly of the global leakage matrix is somewhat different. The form of the leakage term arose in part from the introduction of the trial solution for the head in the second aquifer (eq. 10) into equation 13. If nodes $i$ and $j$ in the element nodal system not only 
correspond to nodes $p$ and $q$ in the global nodal system for the first aquifer but also correspond to nodes $k$ and $m$ in the global nodal system for the second aquifer, then $a_{i j}$ in the element leakage matrix is added to $D_{k m}$ in the global leakage matrix.

\section{Force vector.}

The flux term in the force vector arises because of point sources and sinks and because of distributed sinks. Recharge and pumpage are represented mathematically by point sources and sinks. Evapotranspiration discharge is represented mathematically by distributed sinks. Accordingly, the force vector can be expanded to include these flux terms separately. From the expansion, equation 20 is modified to obtain

$$
F_{i}=\iint_{\Omega} \phi_{i=1}^{m} Q_{k} \delta\left(x-x_{k}, y-y_{k}\right) d x d y+\iint_{\Omega} \phi_{i} E d x d y,
$$

where

$Q_{k}$ is the point volumetric recharge to or pumpage from the aquifer,

$x_{k}$ and $y_{k}$ are the coordinates of the location of the point source or sink,

$\delta$ is the Dirac delta function,

$m$ is the number of point sources and sinks, and

$E$ is the volumetric evapotranspiration discharge per unit area.

Because of the properties of the Dirac delta function (Korn and Korn, 1961, p. 876), the integral

$$
\iint_{\Omega} \phi_{i} \sum_{k=1}^{m} Q_{k} \delta\left(x-x_{k}, y-y_{k}\right) d x d y
$$

is equal to $Q_{k}$, if $x_{k}$ and $y_{k}$ are the coordinates of a node. The global force vector is assembled by simply adding $Q_{k}$ to $F_{i}$, where $Q_{k}$ is located at the node $i$.

Distributed sinks are handled somewhat differently. The discharge per unit area is given by the relations

$$
\begin{array}{ll}
E(x, y)=E_{0} & z<0 \\
E(x, y)=E_{0}-\frac{E_{0} z(x, y)}{z_{0}} & \text { for } 0 \leqslant z \leqslant z_{0} \\
E(x, y)=0 & \text { for } \mathrm{z}>z_{0},
\end{array}
$$


where

$E$ is the volumetric discharge per unit area,

$E_{0}$ is the discharge when the water table is at the land surface, $z$ is the depth below the land surface to the water table, and

$z_{0}$ is the depth at which discharge ceases.

The function $E$ can be approximated by using trial functions to interpolate nodal values over an element. The function $E$ is replaced by the series

$$
E(x, y) \simeq \sum_{j=1}^{n} E_{j} \phi_{j}(x, y)
$$

where $E_{j}$ is the value of $E$ at the node $j$. The integral

$$
\iint_{\Omega} \phi_{i} E d x d y
$$

is then replaced by the integral

$$
\iint_{\Omega} \phi_{i} \sum_{j=1}^{n} E_{j} \phi_{j} d x d y .
$$

This integral is best evaluated on an element basis. A typical element force vector $\{f\}$ will be of the form

$$
\{f\}=\iint\left[\begin{array}{lll}
\omega_{1} \omega_{1} & \omega_{1} \omega_{2} & \omega_{1} \omega_{3} \\
\omega_{2} \omega_{1} & \omega_{2} \omega_{2} & \omega_{2} \omega_{3} \\
\omega_{3} \omega_{1} & \omega_{3} \omega_{2} & \omega_{3} \omega_{3}
\end{array}\right] d x d y\left(\begin{array}{l}
E_{1} \\
E_{2} \\
E_{3}
\end{array}\right)
$$

The integrations in equation 34 are evaluated by using equations 28 and 29. If node $i$ in the element nodal system corresponds to node $p$ in the global nodal system, then the global force vector is assembled by adding $f_{i}$ in the element force vector to $F_{p}$ in the global force vector.

\section{FINITE-DIFFERENCE APPROXIMATION OF THE TIME DERIVATIVE}

Although the matrices $[A],[B]$, and $[D]$ and the vector $\{F\}$ can now be evaluated, we must still solve the set of ordinary differential equations

$$
[A]\{C\}+[B]\left\{\frac{d C}{d t}\right\}+[D]\left\{C^{\prime}\right\}+\{F\}=0
$$


To do this we approximate the time derivative by using the first-order correct, implicit, finite-difference scheme

$$
[A]\left\{C_{t+\Delta t}\right\}+\frac{1}{\Delta t}[B]\left\{C_{t+\Delta t}-C_{t}\right\}+[D]\left\{C^{\prime}{ }_{t+\Delta t}\right\}+\{F\}=0 .
$$

Equation 35 can be rearranged to obtain

$$
\left([A]+\frac{1}{\Delta t}[B]\right)\left\{C_{t+\Delta t}\right\}+[D]\left\{C^{\prime}{ }_{t+\Delta t}\right\}=\frac{1}{\Delta t}[B]\left\{C_{t}\right\}-\{F\} .
$$

Equation 36 applies to the first aquifer. The parallel expression for the second aquifer is

$$
\left(\left[A^{\prime}\right]+\frac{1}{\Delta t}\left[B^{\prime}\right]\right)\left\{C^{\prime}{ }_{t+\Delta t}\right\}+\left[D^{\prime}\right]\left\{C_{t+\Delta t}\right\}=\frac{1}{\Delta t}\left[B^{\prime}\right]\left\{C^{\prime} t\right\}-\left\{F^{\prime}\right\} .
$$

\section{ASSEMBLY OF THE TWO-AQUIFER SOLUTION}

The simultaneous solution of equations 36 and 37 for $\left\{C_{t+\Delta t}\right\}$ and $\left\{C^{\prime}{ }_{t+\Delta t}\right\}$ can be obtained by first assembling the matrix equation

$$
\left([\Pi]+\frac{1}{\Delta t}[\mathrm{Y}]\right)\left\{\mathrm{X}_{t+\Delta t}\right\}=\frac{1}{\Delta t}[\mathrm{Y}]\left\{\mathrm{X}_{t}\right\}-\{\Psi\},
$$

where

$$
\begin{aligned}
& {[\Pi] \equiv } {\left[\begin{array}{c}
{[A][D]} \\
{\left[D^{\prime}\right]\left[A^{\prime}\right]}
\end{array}\right] } \\
& {[\mathrm{Y}] \equiv } {\left[\begin{array}{cc}
{[B]} & O \\
O & {\left[B^{\prime}\right]}
\end{array}\right] } \\
&\left\{\mathrm{X}_{t}\right\} \equiv\left\{\begin{array}{c}
\left\{C_{t}\right\} \\
\left\{C^{\prime}{ }_{t}\right\}
\end{array}\right\} \\
&\left\{\mathrm{X}_{t+\Delta t}\right\} \equiv\left\{\begin{array}{c}
\left\{C_{t+\Delta t}\right\} \\
\left\{C^{\prime}{ }_{t+\Delta t}\right\}
\end{array}\right\} \\
&\{\Psi\} \equiv\left\{\begin{array}{c}
\{F\} \\
\left\{F^{\prime}\right\}
\end{array}\right\}
\end{aligned}
$$

Equation 38 can then be solved for $\left\{\mathrm{X}_{t+\Delta t}\right\}$, which can be easily decomposed into $\left\{C_{t+\Delta t}\right\}$ and $\left\{\mathrm{C}_{t+\Delta t}^{\prime}\right\}$. 


\section{RECURRENCE ALGORITHM}

To bring together the concepts outlined up to this point, the solution scheme for obtaining heads in the two-aquifer system at discrete points in space and time will be presented in a stepwise fashion.

Step 1.-Evaluate $[A],[B],[D],\left[A^{\prime}\right],\left[B^{\prime}\right]$, and $\left[D^{\prime}\right]$ and assemble $[\Pi]$ and $[Y]$.

Step 2.-Assign the initial heads to $\left\{\mathrm{X}_{t}\right\}$.

Step 3.-Evaluate

$$
[\Pi]+\frac{1}{\Delta t}[Y] \text {. }
$$

Step 4.-Evaluate $\{F\}$ and $\left\{F^{\prime}\right\}$ and assemble $\{\Psi\}$. The evapotranspiration discharge (eq. 33) depends on the head in the aquifer. Because this discharge is nonlinearly related to the head, equation 38 is also nonlinear. To maintain the linearity of this equation, we can devise a numerical scheme wherein the evapotranspiration discharge is obtained by extrapolating head values from earlier known time levels to the current, unknown, level. An extrapolation based on the latest two calculated heads provides satisfactory results. Notice, however, that we solve this nonlinear system of equations only approximately when using this quasi-linearization procedure.

Step 5.-Evaluate the vector

$$
\frac{1}{\Delta t}[Y]\left\{X_{t}\right\}-\{\Psi\} \text {. }
$$

Step 6.-Solve equation 38 for $\left\{\mathrm{X}_{\mathrm{t}+\Delta t}\right\}$ by the point iterative successive over-relaxation method (Varga, 1962). $\left\{\mathrm{X}_{t+\Delta t}\right\}$ then can be easily decomposed into $\left\{\mathrm{C}_{\mathrm{t}+\Delta t}\right\}$ and $\left\{\mathrm{C}_{\mathrm{t}+\Delta \mathrm{t}}^{\prime}\right\}$. Consequently, the previously undetermined coefficients in the trial solutions

$$
\hat{h}(x, y, t)=\sum_{i=1}^{n} C_{i}(t) \phi_{i}(x, y)
$$

and

$$
\hat{h}^{\prime}(x, y, t)=\sum_{i=1}^{n^{\prime}} C_{i}^{\prime}(t) \phi_{i}^{\prime}(x, y)
$$

are now known, and these solutions can be used to approximate the continuous distribution of heads in the aquifers. Recall that the trial functions were defined such that they are unity at the node for which they are defined and they are zero at every other node. Because of these characteristics of the trial functions, the trial solutions reduce at the nodal locations to 


$$
\hat{h}\left(x_{k}, y_{k}, t\right)=C_{k}(t)
$$

and

$$
\hat{h}^{\prime}\left(x_{k}^{\prime}, y_{k}^{\prime}, t\right)=C_{k}^{\prime}(t)
$$

where $x_{k}$ and $y_{k}$ are the coordinates of node $k$ in the first aquifer and $x_{k}^{\prime}$ and $y_{k}^{\prime}$ are the coordinates of node $k$ in the second aquifer. At the nodal locations, heads in the aquifers are the coefficients $C_{k}$ and $C_{k}^{\prime}$.

Step 7.-Replace $\left\{\mathrm{X}_{t}\right\}$ with $\left\{\mathrm{X}_{t+\Delta t}\right\}$.

Step 8.-Add $\Delta t$ to the elapsed time. Then, if $\Delta t$ has been changed, return to step 3; otherwise return to step 4.

The above cycle is repeated until the desired period of simulation is covered.

\section{SUMMARY}

The Antelope Valley ground-water basin, which has a surface area of $900 \mathrm{mi}^{2}\left(2,300 \mathrm{~km}^{2}\right)$ and a thickness of as much as $5,000 \mathrm{ft}(1,500$ $\mathrm{m})$, consists of two alluvial aquifers separated by fine-grained lacustrine deposits that are as much as $400 \mathrm{ft}(120 \mathrm{~m})$ thick. Natural recharge to the ground-water basin occurs mostly by the infiltration of streamflow. The average annual recharge is 40,700 acre- $\mathrm{ft}$ (50.2 $\mathrm{hm}^{3}$ ). Before the extensive use of ground water for agriculture, the ground-water system was in equilibrium, and the recharge equaled the discharge, which occurred mainly by evapotranspiration.

Extensive pumping of ground water has caused the suppression of evapotranspiration of ground water, and pumping is presently the principal means of discharge from the ground-water basin. During the last 50 years, pumping of ground water in excess of natural recharge has resulted in the decline of water levels as much as $200 \mathrm{ft}$ $(61 \mathrm{~m})$. Cumulative pumpage for the period before 1973 is about 10 million acre-ft $\left(12,000 \mathrm{hm}^{3}\right)$.

Part of the applied irrigation water is consumed by the crop, and part percolates below the root zone. A large part of the cumulative percolate may be stored in the unsaturated zone, and the recharge of the zone of saturation by irrigation return may have been small through the end of the calibration period, 1961.

A mathematical model of the ground-water basin was developed on the basis of a simplified conceptualization of the ground-water system. The model was calibrated by comparing the computed hydraulic heads with the corresponding prototype water levels for both steadystate and transient-state conditions. For the steady-state model, the area-weighted median absolute deviation of computed hydraulic heads from the prototype water levels was $12 \mathrm{ft}(3.7 \mathrm{~m})$. For the transient-state model, the median deviation was $25 \mathrm{ft}(7.6 \mathrm{~m})$.

The data used to calibrate the model contained errors. These errors 
in part caused the observed deviation of the computed hydraulic heads from the prototype water levels. The errors contained both systematic and random components. In general, the systematic errors were probably transferred to the parameters during the calibration procedure.

Predictions made with the model will be in error because of the transfer of data errors to the aquifer parameters during the calibration. The predictions will also contain errors that can be related to the initial conditions and assumed future pumpage. If these three types of errors are present, the median error of water-level prediction will probably be about the same as obtained from calibration of the transient-state model, or about $25 \mathrm{ft}(7.6 \mathrm{~m})$, if a similar magnitude and duration of pumping are considered.

Prediction errors due to initial conditions and the assumed pumpage can be eliminated if the model interrogation is designed to predict the differential response of the prototype to different pumpage characteristics. If the model is interrogated in this manner, the median error of prediction will probably be substantially less than $25 \mathrm{ft}$ $(7.6 \mathrm{~m})$.

\section{REFERENCES CITED}

Blaney, H. F., Taylor, C. A., and Young, A. A., 1930, Rainfall penetration and consumptive use of water in Santa Ana River valley and coastal plain: California Dept. Public Works, Div. Water Resources Bull. 33, 162 p.

Bloyd, R. M., Jr., 1967, Water resources of the Antelope Valley East-Kern Water Agency area, California: U.S. Geol. Survey open-file report, 73 p.

California Department of Water Resources, 1947, Report to the Assembly of the State Legislature on water supply of Antelope Valley in Los Angeles and Kern Counties pursuant to House Resolution Number 101 of February 16, 1946: 21 p.

1957, The California water plan: Bull. 3, 246 p.

California State Water Resources Control Board, 1974, Water quality control plan report, South Lahontan basin: $300 \mathrm{p}$.

Carpenter, E. J., and Cosby, S. W., 1926, Soil survey of the Lancaster area, California: U.S. Dept. Agriculture, 97 p.

Dibblee, T. W., Jr., 1967, Areal geology of the western Mojave Desert, California: U.S. Geol. Survey Prof. Paper 522, 153 p.

Dutcher, L. C., Bader, J. S., Hiltgen, W. J., and others, 1962, Data on wells in the Edwards Air Force Base area, California: California Dept. Water Resources Bull. 91-6, $209 \mathrm{p}$.

Dutcher, L. C., and Garrett, A. A., 1963, Geologic and hydrologic features of the San Bernardino area, California, with special reference to underflow across the San Jacinto fault: U.S. Geol. Survey Water-Supply Paper 1419, 114 p.

Dutcher, L. C., and Worts, C. F., Jr., 1963, Geology, hydrology, and water supply of Edwards Air Force Base, Kern County, California: U.S. Geol. Survey open-file report, $225 \mathrm{p}$.

Forray, M. J., 1968, Variational calculus in science and engineering: New York, McGraw-Hill, 193 p. 
Galerkin, B. G., 1915, Rods and plates: Vestn. Inzh. Tech. (USSR) rept. 19, p. 897908. Translation 63-18924, Clearinghouse Federal Sci. Tech. Inf.

Hedman, E. R., 1970, Mean annual runoff as related to channel geometry of selected streams in California: U.S. Geol. Survey Water-Supply Paper 1999-E, 17 p.

Hutton, S. G., and Anderson, D. L., 1971, Finite element method-a Galerkin approach: Am. Soc. Civil Engineers, Mech. Div. Jour., v. 7, no. 5, p. 1503-1520.

Johnson, H. R., 1911, Water resources of Antelope Valley, California: U.S. Geol. Survey Water-Supply Paper $278,92 \mathrm{p}$.

Koehler, J. H., 1966, Data in water wells in the eastern part of the Antelope Valley area, Los Angeles County, California: California Dept. Water Resources Bull. 91-12, 17 p., 6 app.

Korn, G. A., and Korn, T. M., 1961, Mathematical Handbook for scientists and engineers: New York, McGraw-Hill, 1130 p.

Lee, C. H., 1912, An intensive study of the water resources of a part of Owens Valley, California: U.S. Geol. Survey Water-Supply Paper 294, 135 p.

Leopold, L. B., and Wolman, M. G., 1957, River channel patterns: braided, meandering, and straight: U.S. Geol. Survey Prof. Paper 282-B, p. 39-85.

Lohman, S. W., 1972, Ground-water hydraulics: U.S. Geol. Survey Prof. Paper 708, $70 \mathrm{p}$.

Mabey, D. R., 1960, Gravity survey of the western Mojave Desert, California: U.S. Geol. Survey Prof. Paper 316-D, p. 51-73.

Moore, D. O., 1968, Estimating mean runoff in ungaged semiarid areas: Internat. Assoc. Sci. Hydrology Bull. 13, v. 1, p. 29-39.

Moyle, W. R., Jr., 1965, Water wells in the western part of the Antelope Valley area, Los Angeles and Kern Counties, California: California Dept. Water Resources Bull. 91-11, 16 p., 6 app.

Pinder, G. F., and Frind, E. O., 1972, Application of Galerkin's procedure to aquifer analyses: Water Resources Research, v. 8, no. 1, p. 108-120.

Poland, J. F., Piper, A. M., and others, 1956, Ground-water geology of the coastal zone, Long Beach-Santa Ana area, California: U.S. Geol. Survey Water-Supply Paper $1109,162 \mathrm{p}$.

Rantz, S. E., 1969, Mean annual precipitation in the California region: U.S. Geol. Survey open-file report, $5 \mathrm{p}$.

Robinson, T. W., 1958, Phreatophytes: U.S. Geol. Survey Water-Supply Paper 1423, $84 \mathrm{p}$.

Snyder, J. H., 1955, Ground water in California-The experience of Antelope Valley: Univ. California, Div. Agri. Sci., Giannini Foundation ground-water rept. no. 2, $171 \mathrm{p}$.

Theis, C. V., 1963, Estimating the transmissibility of a water-table aquifer from the specific capacity of a well, in Bentall, Ray, compiler, Methods of determining permeability, transmissibility, and drawdown: U.S. Geol. Survey Water-Supply Paper 1536-I, p. 332-336.

Thompson, D. G., 1929, The Mohave Desert region, California, a geographic, geologic, and hydrologic reconnaissance: U.S. Geol. Survey Water-Supply Paper 578, 759 p.

Varga, R. S., 1962, Matrix iterative analyses: Englewood Cliffs (New Jersey), Prentice Hall, 322 p.

Wright, R. V., 1924, Antelope Valley, California-Report on agricultural, economic, and ground-water situation: Federal Land Bank of Berkeley, 203 p.

Young, A. A., and Blaney, H. F., 1942, Use of water by native vegetation: California Dept. Water Resources Bull. 50, 160 p. 